\title{
International Trade and Investment Agreements as Barriers to Food Environment Regulation for Public Health Nutrition: A Realist Review
}

\author{
Kelly Garton $^{1^{(\mathbb{D}}}$, Anne Marie Thow $^{2^{(}}$, Boyd Swinburn $^{1(\mathbb{D}}$
}

\begin{abstract}
Background: Achieving healthy food systems will require regulation across the supply chain; however, binding international economic agreements may be constraining policy space for regulatory intervention in a way that limits uptake of 'best-practice' nutrition policy. A deeper understanding of the mechanisms through which this occurs, and under which conditions, can inform public health engagement with the economic policy sector.

Methods: We conducted a realist review of nutrition, policy and legal literature to identify mechanisms through which international trade and investment agreements (TIAs) constrain policy space for priority food environment regulations to prevent non-communicable diseases (NCDs). Recommended regulations explored include fiscal policies, product bans, nutrition labelling, advertising restrictions, nutrient composition regulations, and procurement policies. The process involved 5 steps: initial conceptual framework development; search for relevant empirical literature; study selection and appraisal; data extraction; analysis and synthesis, and framework revision.

Results: Twenty-six studies and 30 institutional records of formal trade/investment disputes or specific trade concerns (STCs) raised were included. We identified 13 cases in which TIA constraints on nutrition policy space could be observed. Significant constraints on nutrition policy space were documented with respect to fiscal policies, product bans, and labelling policies in 4 middle-income country jurisdictions, via 3 different TIAs. In 7 cases, trade-related concerns were raised but policies were ultimately preserved. Two of the included cases were ongoing at the time of analysis.

TIAs constrained policy space through 1) TIA rules and principles (non- discrimination, necessity, international standards, transparency, intellectual property rights, expropriation, and fair and equitable treatment), and 2) interaction with policy design (objectives framed, products/services affected, nutrient thresholds chosen, formats, and time given to comment or implement). Contextual factors of importance included: actors/institutions, and political/regulatory context.

Conclusion: Available evidence suggests that there are potential TIA contributors to policy inertia on nutrition. Strategic policy design can avoid most substantive constraints. However, process constraints in the name of good regulatory practice (investor-state dispute settlement (ISDS), transparency, regulatory coherence, and harmonisation) pose a more serious threat of reducing government policy space to enact healthy food policies.

Keywords: Non-communicable Diseases (NCDs), Nutrition Policy, International Trade, Investment Agreements, Policy Analysis

Copyright: (c) 2021 The Author(s); Published by Kerman University of Medical Sciences. This is an open-access article distributed under the terms of the Creative Commons Attribution License (https://creativecommons.org/licenses/ by/4.0), which permits unrestricted use, distribution, and reproduction in any medium, provided the original work is properly cited.

Citation: Garton K, Thow AM, Swinburn B. International trade and investment agreements as barriers to food environment regulation for public health nutrition: a realist review. Int J Health Policy Manag. 2021;10(12):745765. doi:10.34172/ijhpm.2020.189
\end{abstract}

Article History:

Received: 29 May 2020

Accepted: 28 September 2020 ePublished: 19 October 2020

View Video Summary

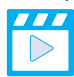

*Correspondence to:

Kelly Garton

Email:

kelly.garton@gmail.com

\section{Background}

The past 30 years has seen a sea change of economic globalisation and liberalisation, which has opened up markets and harmonised regulations following the highly constrained world of tariffs, national protections, and restricted trade for much of the 20th century. In this policy environment the food industry pursued a path of expansion in terms of the size and power of trans-national companies (TNCs) being concentrated to major companies, especially food manufacturers producing certain types of ultra-processed foods such as snack foods and carbonated beverages, and other products high in salt, fats, and sugars. The adverse health effects of consuming such products are well-known. ${ }^{1-9}$ These companies and products penetrated low- and middle-income countries (LMICs) in an unprecedented way, ${ }^{10-14}$ coinciding with a dramatic increase in the prevalence of obesity and noncommunicable diseases (NCDs) in all LMICs. ${ }^{15-19}$ In highincome countries, some NCDs like cardiovascular disease have reduced, but others like obesity and diabetes have increased inexorably. ${ }^{15,20}$ Malnutrition in all its forms is now by far the biggest contributor to lost disability-adjusted life years around the world. ${ }^{21}$

Such trends have prompted recommendations from the World Health Organization (WHO) for regulatory actions to prevent diet-related NCDs, including measures addressing labelling, price, marketing and nutrient composition..$^{22-24}$ 
However, despite these being evidence-based, and globally agreed at the World Health Assembly, they are only sporadically implemented. ${ }^{25}$ This regulatory 'failure to launch', or policy inertia, is often attributed to industry opposition, instilling government reluctance, and public quiescence. ${ }^{21,26,27}$ Part of this policy inertia may be constriction of policy space from international trade and investment agreements (TIAs). ${ }^{28,29}$ Policy space refers to "the freedom, scope, and mechanisms that governments have to choose, design, and implement public policies to fulfil their aims." ${ }^{30}$ This concept therefore includes not only the ability or right of states to regulate, but also the range of content and restrictions that policies can cover, and the processes through which policy can be chosen, designed, and implemented. WHO recommendations are not binding, but World Trade Organization (WTO) and other free TIAs are, and have binding dispute settlement mechanisms. Commitments made under TIAs can thus constrain countries' ability to regulate goods, services, intellectual property and investments to promote public interests (including public health and the environment) upstream from domestic policy processes. ${ }^{31}$

The high-profile investment dispute launched by tobacco giant Philip Morris Asia against tobacco plain packaging policy in Australia (2011) demonstrates the high stakes governments face when developing health-related product regulations. ${ }^{32}$ Although Australia successfully defended their regulation in international arbitration, it cost more than $\mathrm{A} \$ 23$ million (half of which was repaid by the claimant, leaving Australia A\$12 million out-of-pocket), ${ }^{33}$ and had a chilling effect on other countries following suit. ${ }^{34}$ Faced with the risk of arbitration and settlement of a lost dispute, governments may abandon, alter, or fail to enforce certain policy proposals, even if made in good faith. Domestic regulatory vetting processes to mitigate such risks ie, regulatory impact assessments (RIAs), mean that 'regulatory chill' can occur before policy is even developed. ${ }^{35,36}$

Government policies are needed to drive the transition towards food systems that are better suited to 21st century challenges, including reducing the enormous health and economic burden of NCDs. This review is designed to foster policy learning globally, to understand the constraints to policy-making created by TIAs and to what extent they can be averted through strategic policy design.

\section{Methods}

We undertook a review of global evidence on how TIAs have or could affect policy space for a series of food environment interventions for preventing NCDs guided by the realist review method. As such, this paper identifies the ways in which TIAs influence the policy space for key nutrition policies that aim to prevent NCDs. A deeper understanding of the mechanisms through which this occurs, and under which conditions, could inform public health engagement with the economic policy space. The findings here may also apply to strategic regulation of food industries to combat climate change and other environmental damage, and for NCD prevention through regulation of other unhealthy commodities.
Realist review is a theory-driven, interpretive approach to the synthesis of evidence on an intervention to examine what works, for whom, under what circumstances, and in what respects ${ }^{37}$ and has been used previously to examine complex nutrition policy questions..$^{38,39}$ The approach is focussed on gathering and synthesising evidence of "the contextual (C) influences that are hypothesized to have triggered the relevant mechanism(s) (M) to generate the outcome $(\mathrm{s})(\mathrm{O})$ of interest." ${ }^{40}$ In the present study, we consider the intervention to be a country's membership in/acceding to TIAs; a complex and context-sensitive intervention, because one could expect the same TIA to produce different outcomes in different country contexts and for specific policy proposals. In this study:

- Contexts (C) relate to the governments (local, state or regional) seeking to implement policy.

- Mechanisms (M) are causal forces or powers that contribute to a certain policy space outcome. This study examined any mechanism of action through which the 'intervention' of international trade and investment operates to influence policy space.

- Outcomes (O) were conceptualised as the impact on specific policy, either proposed or already in effect, in terms of whether a proposed/implemented policy was preserved, modified, delayed, compromised or abandoned.

In our analysis of the review findings, we drew on political economy analysis to examine how power and resources are distributed and contested in different contexts, and the implications for food environment policy outcomes.

The stages of realist review follow a systematic process of 5 steps: initial scoping of the literature for conceptual framework development; search for relevant empirical literature; study selection and appraisal; data extraction; analysis and synthesis, and framework revision. ${ }^{41}$ No major changes were made to the review process once initiated.

\section{Scoping the Literature}

Through a preliminary scoping of the literature related to international trade and investment, public health and NCD prevention, food environment regulation, and policy space, we identified 8 foundational sources to develop an initial conceptual framework to guide the review (see Figure 1).

Contexts: Voon et $\mathrm{al}^{42}$ suggest that political and regulatory contexts affect the impact of TIAs on policy space, including the state of evidence for need and effectiveness of proposed regulation; domestic policy and constitutional law; existing international (human rights, trade, and investment) treaty obligations; politico-economic ties, investment contracts, and import/export profiles. We hypothesized relevant agentrelated factors might include: the presence and power of foodrelated industries; political persuasion and risk-tolerance of government; or social/cultural characteristics of the population.

Mechanisms: This section of the framework included any forces that influence regulatory freedoms and scope (of policy tools) substantively, procedurally and structurally ${ }^{[1]}{ }^{43}$ Following Schram and colleagues' ${ }^{34}$ conceptual framework 


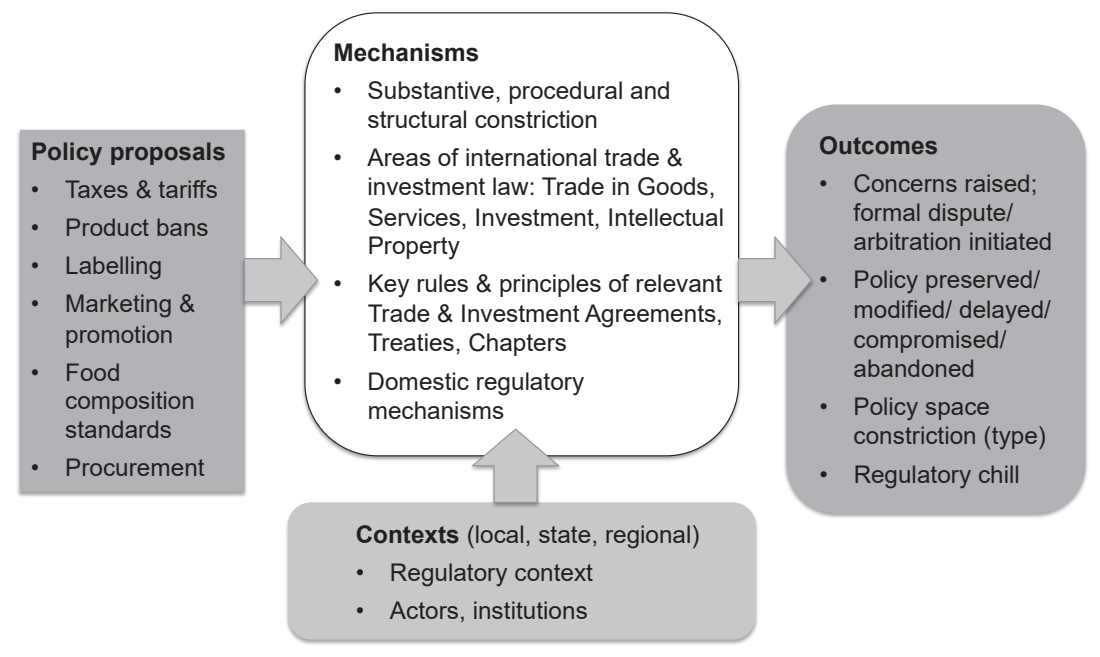

Figure 1. Initial Conceptual Framework for Contexts, Mechanisms and Outcomes of TIA Influences on Policy Space for Food Environment Regulations, Based on Literature Scoping. Abbreviation: TIA, trade and investment agreement.

for investigating the impacts of TIAs on NCD risk factors, we included regulatory coherence provisions, sanitary and phytosanitary (SPS) standards and technical barriers to trade (TBT), investment chapters, and government procurement provisions as having potential influence on domestic policy space and governance for NCD prevention. We combined this with Kelsey's ${ }^{45}$ outline of the legal issues underlying the various aspects of TIAs that may affect policy space for tobacco control in New Zealand: trade in goods; TBT; intellectual property rights; investor promotion, protection and enforcement; trade in services; mutual recognition; transparency and regulatory coherence. We added internal government policy process factors (eg, policy criteria, regulatory vetting procedures such as RIAs, and bureaucratic hierarchy) from Kelsey, ${ }^{34}$ as well as political/economic factors (eg, political will, public support, lobbying, and financial capacity) from Schram et $\mathrm{al}^{46}$ as potential contributors to regulatory chill.

Outcomes: Applying the definition of policy space from Koivusalo et $\mathrm{al}^{30}$ described above, we separated policy space outcomes into the types of policy space constriction described by Fidler ${ }^{43}$ : substantive constriction, procedural constriction, and structural constriction. We note the outcomes of constriction in terms of whether a proposed/implemented policy was preserved, modified, delayed, compromised or abandoned. ${ }^{46}$ We considered regulatory chill ${ }^{34,36,46}$ a potential outcome, though with the caveat that this is difficult to observe empirically (ie, hard to observe regulatory proposals that did not proceed). We conceptualised more proximal outcomes as: whether concerns were raised to the relevant committees or governing bodies (eg, specific trade concerns [STCs] raised in the WTO TBT Committee) or formal disputes or arbitration undertaken.

\section{Search Strategy}

The search for evidence included 5 academic databases covering various disciplines, 13 institutional websites, and 4 dispute databases. For feasibility, the search was limited to sources specifically covering food and/or non-alcoholic beverages regulated for public health nutrition/NCD prevention. Iterative searches were performed to settle on the best possible combination of search terms for collecting relevant results. Evidence gathered from the academic and grey literature search described above was complemented with a purposive search of evidence within trade and investment dispute databases.

\section{Selection and Appraisal of Documents}

Progressive screening of the academic and grey literature began with reviewing the titles of the search results for relevance to our conceptual framework (see Figure 1). Titles were screened by Author $1(\mathrm{KG})$, and were retained if they related to:

- Nutrition policy in general, or any of the framework's nutrition policy domains; and

- International trade and investment in general, or at least one of the framework's mechanisms of interest; and

- Policy space (or a related term) in general, or a specific framework policy outcome.

Because of the high number of results, we reviewed only the first $500-600$ citations generated by each database, at which point no more relevant titles appeared (see Figure 2). The abstracts from this resulting list of retained titles were then reviewed for relevance and type of evidence, by KG with a second reviewer [BS] (See Table 1 for detail of inclusion/ exclusion criteria). Once a final list of abstracts was established by both reviewers, we assessed the rigour of each full source to determine final inclusion in the review, in accordance with Realist and Meta-narrative Evidence Syntheses: Evolving Standards guidelines. ${ }^{41}$ We did not have to remove any sources from the final sample due to lack of rigour.

For each of the trade and investment database sources, selection for inclusion involved first reviewing case titles for relevance to the aforementioned policy areas (see Figure 2). For the titles retained, case summaries were read to include cases where the policies had clear public health nutrition objectives, and to exclude any cases related to food safety and 


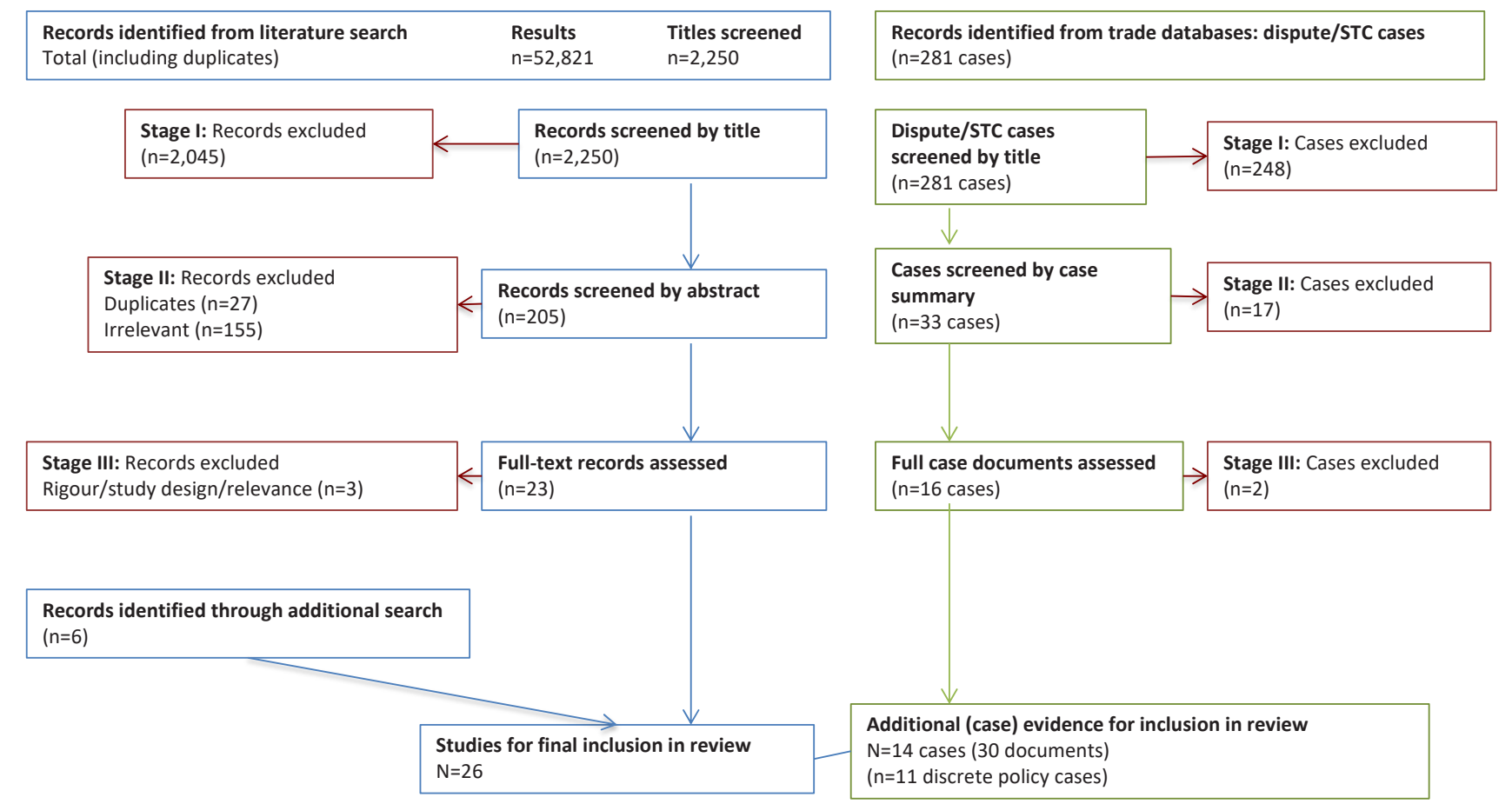

Figure 2. Document Search, Selection and Appraisal Flow Diagram. Abbreviation: STC, specific trade concern.

biosecurity, environmental or animal welfare concerns, 'fair trade, or other consumer preferences (See Table 1). A decision was made to exclude energy drinks because the issues in question were mainly about food safety. Finally, inclusion was determined based on the availability and clarity of full case documentation such as arbitration meeting minutes and TBT Committee meeting minutes. For each retained case, all of the available documentation (eg, Appellate Body reports, TBT Committee meeting minutes, and arbitration panel reports) were reviewed.

\section{Data Extraction}

Information was extracted from each study or case on: the country context, the agreement or treaty in question, the policy area(s) discussed, policy outcomes, and the mechanisms through which the policy was/was not/could be affected, paying particular attention to information that confirmed, refined, substantiated or refuted existing theories. The data analysis matrix in which we collected data was thus developed based on the provisional conceptual framework, and adapted/ expanded throughout the data collection phase. We uploaded all documents to $\mathrm{NVivo}^{47}$ for qualitative analysis involving the coding of C-M-O factors and key themes. Finally, we reviewed sources' reference lists for potential additional literature to include.

\section{Analysis and Synthesis Processes}

We used NVivo ${ }^{47}$ to sort and organise the data extracted from the papers in line with the C-M-O framework, and to record any key themes, factors or concepts identified through iterative reading of the literature relating to the development of theory from the provisional conceptual framework. To begin, a set of codes was assigned for each of the C-M-O factors hypothesised in the initial provisional conceptual framework. For each text source, we recorded (as relevant): contexts (eg, country, domestic policy characteristics, economic relations, import/export profile, and population nutrition profile, social-cultural factors), mechanisms (eg, specific TIAs mentioned and rules/principles invoked), outcomes (challenge status, policy status, type of policy space constriction), policy-specific factors (eg, type of policy tool, policy content factors, policy process factors), as well as any related theory or case law. While reading each source, we tagged the relevant text as it appeared, and also added new codes to this list through iterative reading of the sources. Once each of the texts had been coded, we ran queries to assess the density of each factor/theme (how often it comes up in the data), and to ascertain the relationships between codes, and coding summaries for more in-depth reading to identify embedded patterns and sub-themes.

\section{Results and Analysis \\ Document Characteristics}

We included 26 studies or reports, and 30 institutional case documents of formal trade/investment disputes or STCs raised in this review (Figure 2). Twelve studies and 30 institutional records presented empirical evidence, from which we identified 13 cases in which TIA constraints on nutrition policy space could be observed (Table 2). Nutrition policy space constraints $(\mathrm{O})$ were documented with respect to fiscal policies, product bans, nutrition labelling, and nutrient limit policies in 12 jurisdictions (C), via the following TIAs (M): the WTO General Agreement on Tariffs and Trade (GATT), the North American Free Trade Agreement (NAFTA), and the WTO Agreement on Technical Barriers to Trade (WTO TBT), and the European Community Treaty (EC Treaty). We 


\begin{tabular}{|c|c|c|c|}
\hline Search & Databases/Institutional Websites & Search Terms & Inclusion/Exclusion Criteria \\
\hline $\begin{array}{l}\text { Academic } \\
\text { literature }\end{array}$ & $\begin{array}{l}\text { Scopus, PubMed, EBSCOhost Index to } \\
\text { Legal Periodicals and Books, Westlaw } \\
\text { International, HeinOnline }\end{array}$ & \multirow{2}{*}{$\begin{array}{l}\text { trade OR investment } \\
\text { - AND - } \\
\text { food OR drink OR beverage OR diet } \\
\text { - AND - } \\
\text { policy OR "policy space" OR "regulatory space" OR } \\
\text { "regulatory autonomy" OR "regulatory chill" OR } \\
\text { concern OR dispute } \\
\text { - AND - } \\
\text { label* OR packag* OR warning OR tax OR ban OR } \\
\text { marketing OR advertising OR promotion OR standard } \\
\text { OR composition OR procurement }\end{array}$} & \multirow[b]{2}{*}{$\begin{array}{l}\text { Studies/reports were included if: } \\
\text { Published after } 1995 \text { in English, in a peer-reviewed journal or by an official organisation or non-government organisation } \\
\text { with a mandate to address public health or international trade; and } \\
\text { Identified and described factors related to international trade, policy space, and at least one of the nutrition policy } \\
\text { domains of interest (rather than questions of domestic regulatory authority); and } \\
\text { Involved an empirical analysis using primary sources as data; for legal papers and reports, if either interpreted case law or } \\
\text { legal provisions, or presented theoretical research on general concepts, problems and principles related to international } \\
\text { trade and investment law, and its impact on nutrition policy. } \\
\text { Studies were excluded if: } \\
\text { Non-empirical (eg, commentaries); or } \\
\text { Focused on food safety and biosecurity, environmental or animal welfare concerns, fair trade, or other consumer } \\
\text { preferences (eg, organic, halal, wild/farmed, free range, GMO, country of origin, hormones); or } \\
\text { Focused only on domestic policy space or jurisdictional constraints. } \\
\text { Rigour - credibility and trustworthiness. } \\
\text { Studies/reports retained if: } \\
\text { Academic literature was peer-reviewed, authors appeared to have no conflict of interest, and producers of grey literature } \\
\text { were reputable international organisations; and } \\
\text { Clearly articulated study methods, and stated methods were deemed appropriate to fulfil study aims. }\end{array}$} \\
\hline $\begin{array}{l}\text { Grey } \\
\text { literature }\end{array}$ & $\begin{array}{l}\text { Codex Alimentarius, FAO, ICSID, ICTSD, } \\
\text { IFPRI, IISD, OHCHR, USTR, UNCTAD, } \\
\text { WCRF, WHO, WIPO, WTO }\end{array}$ & & \\
\hline \multirow[b]{2}{*}{$\begin{array}{l}\text { Dispute } \\
\text { databases }\end{array}$} & WTO database of formal disputes & Agricultural and food (109 results); soft drinks (1 result) & $\begin{array}{l}\text { Cases were included if they: } \\
\text { Had clear public health nutrition objectives in one of the policy areas of interest (fiscal policy, product bans, regulation of } \\
\text { advertising and marketing, labelling, food composition standards, and procurement). }\end{array}$ \\
\hline & $\begin{array}{l}\text { UNCTAD Investment Dispute } \\
\text { Settlement Navigator }\end{array}$ & $\begin{array}{l}\text { By economic sectors: manufacture of food products } \\
\text { (31); manufacture of beverage products (5); food and } \\
\text { beverage service activities (1) }\end{array}$ & $\begin{array}{l}\text { Cases were excluded if they: } \\
\text { Focused on food safety and biosecurity, environmental or animal welfare concerns, fair trade, or other consumer preferences } \\
\text { (eg, organic, halal, wild/farmed, free range, GMO, country of origin, hormones); or } \\
\text { Had insufficient data and documentation. }\end{array}$ \\
\hline
\end{tabular}

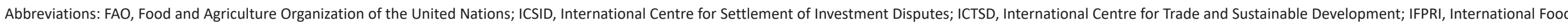

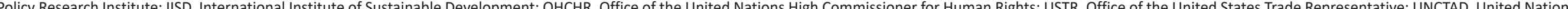
Conference on Trade and Development; WCRE, World Cancer Research Fund; WHO, World Health Organization; WIPO, World Intellectual Property Organization; WTO, World Trade O trade concerns; GMO, genetically modified organism.

* Indicates truncating to capture all variations of the word (eg, packag* captures package, packaged and packaging).

a The Sanitary and Phytosanitary (SPS) STC database was excluded because all existing concerns were related to food safety, not the policies of interest for this study. 
Table 2. Identified Cases Involving Potential TIA Constraints on Nutrition Policy Space

\begin{tabular}{|c|c|c|c|c|}
\hline Contexts & Nutrition Policy (Year Proposed) & Mechanisms: TIAs & TIA Principles Invoked & Outcomes \\
\hline Ghana & $\begin{array}{l}\text { Standards on fat content of meat cuts } \\
\text { (early 1990s) }\end{array}$ & $\mathrm{n} / \mathrm{a}$ & $n / a$ & $\begin{array}{l}\text { No trade concerns identified. } \\
\text { Policy successfully implemented. }{ }^{62}\end{array}$ \\
\hline Mexico & $\begin{array}{l}\text { Tax on soft drinks and other beverages } \\
\text { sweetened with sweeteners other than } \\
\text { cane sugar (imposed 2002) }\end{array}$ & $\begin{array}{l}\text { WTO GATT (1 dispute) } \\
\text { NAFTA ( } 3 \text { disputes) }\end{array}$ & $\begin{array}{l}\text { Discrimination (Art. III National Treatment) } \\
\text { Indirect expropriation, fair and equitable treatment, national treatment, } \\
\text { performance requirements }\end{array}$ & $\begin{array}{l}\text { Decided in favour of complainant. } .^{63} \\
\text { Decided in favour of complainants, compensation awarded. }{ }^{64-66} \\
\text { Policy abandoned. }{ }^{53,60,61}\end{array}$ \\
\hline Denmark & Ban on trans-fatty acids ( $2 \%$ limit) (2003) & EC Treaty & $\begin{array}{l}\text { Restriction on the free movement of goods within the EU (EC Treaty Art. } 28 \text { and Art. } \\
\text { 30) }\end{array}$ & $\begin{array}{l}\text { EC took initial steps toward prosecution, but dropped case } \\
\text { following Denmark's presentation of evidence. }{ }^{52,67} \\
\text { Policy preserved, implemented } 2004 \text {. }\end{array}$ \\
\hline Samoa & $\begin{array}{l}\text { Import ban on turkey tails (implemented } \\
\text { 2007) }\end{array}$ & $\begin{array}{l}\text { Negotiated as part of } \\
\text { acceding to WTO }\end{array}$ & $\begin{array}{l}\text { Discrimination - availability of 'like' products } \\
\text { Necessity - single product ban inappropriate to tackle the complex problem of } \\
\text { obesity }\end{array}$ & Policy abandoned 2011. ${ }^{77,78}$ \\
\hline South Korea & $\begin{array}{l}\text { Revision of nutrition labelling standards } \\
\text { (2008) }\end{array}$ & WTO TBT & $\begin{array}{l}\text { International standards (Codex) } \\
\text { Unnecessary barrier to trade }\end{array}$ & $\begin{array}{l}\text { STCs raised (once). }{ }^{79} \\
\text { Policy preserved, implemented } 2009 .\end{array}$ \\
\hline Mexico & $\begin{array}{l}\text { Revision of nutrition labelling standards } \\
\text { (updated Guideline Daily Amounts) } \\
\text { (2009) }\end{array}$ & WTO TBT & Further information, clarification & $\begin{array}{l}\text { STCs raised (once). }{ }^{80} \\
\text { Policy preserved, implemented } 2011 .\end{array}$ \\
\hline Chile & $\begin{array}{l}\text { Front-of-pack stop sign nutrition warning } \\
\text { label, restrictions on advertising to } \\
\text { children (2013) }\end{array}$ & WTO TBT & $\begin{array}{l}\text { Discrimination } \\
\text { Further information, clarification } \\
\text { International standards } \\
\text { Rationale, legitimacy } \\
\text { Time to adapt, 'reasonable interval' } \\
\text { Transparency } \\
\text { Unnecessary barrier to trade } \\
\text { Other: impact for labelling of small packages, lack of scientific basis for nutrient } \\
\text { thresholds, burdensome requirements, coverage of package surface, placing of } \\
\text { stamp/label, cost increases, consumer misleading, availability of alternatives, short } \\
\text { implementation deadlines }\end{array}$ & $\begin{array}{l}\text { STCs raised ( } 12 \text { times). }{ }^{81-92} \\
\text { Policy preserved, implemented } 2016 \text { (with small modification to } \\
\text { colour and size). }{ }^{5,76,93-95}\end{array}$ \\
\hline Indonesia & Health warning nutrition labelling (2013) & WTO TBT & $\begin{array}{l}\text { Further information, clarification } \\
\text { International standards } \\
\text { Time to adapt, 'reasonable interval' } \\
\text { Transparency } \\
\text { Unnecessary barrier to trade } \\
\text { Other: adverse impact of mandatory health warnings, specifics related to testing }\end{array}$ & $\begin{array}{l}\text { STCs raised (11 times). }{ }^{82-92} \\
\text { Policy modified, delayed until 2019. } .^{55,76} \\
\text { No evidence of an update at time of analysis (2020). }\end{array}$ \\
\hline
\end{tabular}


Table 2. Continued

\begin{tabular}{|c|c|c|c|c|}
\hline Contexts & Nutrition Policy (Year Proposed) & Mechanisms: TIAs & TIA Principles Invoked & Outcomes \\
\hline Ecuador & Traffic light nutrition label (2013) & WTO TBT & $\begin{array}{l}\text { Further information, clarification } \\
\text { International standards } \\
\text { Rationale, legitimacy } \\
\text { Time to adapt, 'reasonable interval' } \\
\text { Transparency } \\
\text { Unnecessary barrier to trade } \\
\text { Other: mandatory nature of requirements, burdensome requirements }\end{array}$ & $\begin{array}{l}\text { STCs raised ( } 12 \text { times). }{ }^{84-92,96-98} \\
\text { Policy preserved, implemented } 2014 .{ }^{75}\end{array}$ \\
\hline Peru & $\begin{array}{l}\text { Front-of-pack stop sign nutrition warning } \\
\text { label (2013) }\end{array}$ & WTO TBT & $\begin{array}{l}\text { Further information, clarification } \\
\text { International standards } \\
\text { Rationale, legitimacy } \\
\text { Time to adapt, 'reasonable interval' } \\
\text { Transparency } \\
\text { Unnecessary barrier to trade } \\
\text { Other: lack of scientific evidence on nutrient thresholds, lack of cost-benefit analysis, } \\
\text { consumer misleading, coverage of more foods and products than notified to WTO }\end{array}$ & $\begin{array}{l}\text { STCs raised (14 times). }{ }^{82-92,96-98} \\
\text { Policy preserved after several modifications, implemented } \\
\text { 2019. }{ }^{75,76}\end{array}$ \\
\hline Bolivia & Traffic light nutrition labelling (2016) & WTO TBT & $\begin{array}{l}\text { Further information, clarification } \\
\text { International standards } \\
\text { Rationale, legitimacy } \\
\text { Transparency/ }\end{array}$ & $\begin{array}{l}\text { STCs raised (once). }{ }^{90} \\
\text { Policy preserved, implemented (2017). }\end{array}$ \\
\hline Saudi Arabia & $\begin{array}{l}\text { Added sugar content limit in certain } \\
\text { foods (2019) }\end{array}$ & WTO TBT & $\begin{array}{l}\text { International standards } \\
\text { Rationale, legitimacy } \\
\text { Time to adapt, 'reasonable interval' } \\
\text { Transparency } \\
\text { Unnecessary barrier to trade } \\
\text { Other: Insufficient scientific evidence, lack of clarity, burdensome requirements, } \\
\text { potential negative effect on market demand }\end{array}$ & STCs raised (twice, ongoing). ${ }^{100,101}$ \\
\hline
\end{tabular}

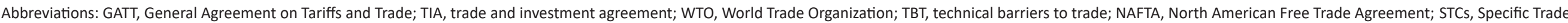
Concerns; EC, European Community. 
observed significant policy space constraints (O) in 4 middleincome country contexts (C): Mexico (fiscal policy), Samoa, Thailand, and Indonesia. In 7 contexts (C: Denmark, Peru, Ecuador, Chile, Bolivia, Mexico (labelling), and South Korea), nutrition policies faced some initial resistance on the grounds of incompatibility with TIAs (M: the EC Treaty, and STCs raised under the WTO TBT), but were justified and preserved (O). STCs raised (M) against nutrition policies in Uruguay and Saudi Arabia (C) are ongoing.

Fourteen studies in the remaining academic and grey literature are largely theoretical or speculative, based on in-depth prospective analysis of the text of the above and other existing agreements, including the WTO Agreement on Trade-Related Aspects of Intellectual Property Rights (TRIPS), ${ }^{48}$ WTO TBT, ${ }^{49-52}$ GATT, ${ }^{49,51,53}$ EC Treaty, ${ }^{54}$ NAFTA, ${ }^{55}$ Trans-Pacific Partnership Agreement (TPPA), ${ }^{56-58}$ United States-Korea Free Trade Agreement (KORUS), ${ }^{57}$ and trade agreements ${ }^{59,60}$ and investment agreements ${ }^{48,61}$ in general.

\section{Outcomes: Summary of Challenges}

The only formal trade and investment challenges raised to date against a public health nutrition policy have been against Mexico's (2002) tax on soft drinks using sweeteners other than cane sugar, which was found to be discriminatory and in violation of obligations under the GATT and NAFTA. ${ }^{63-66}$ While the soft drink tax has the appearance of a nutrition policy, its objective was in fact retaliation for the United States' alleged noncompliance with NAFTA obligations. ${ }^{60}$ The complainants' main issue with the tax was its exclusion (ie, protection) of domestically-produced cane sugar, and thus discrimination against 'like' products-these being all other sweeteners, including high-fructose corn syrup from the United States.

There have also been several instances of constraints on policy space arising through other trade-related mechanisms. An import ban on turkey tails in Samoa was reversed as part of acceding to the WTO. ${ }^{77,78}$ One trade-related concern was the effectiveness of the ban in achieving the objective of improving diets and preventing NCDs-a complex problem-through prohibition of a single food item in the food system (questioning its 'necessity' in light of trade restrictiveness). Another was that other high-fat 'like' foods on the market were not subject to regulation (ie, potential for discrimination).$^{77}$ Interpretive nutrition labelling policies have been subject to STCs raised in the WTO TBT Committee since Thailand first proposed one such initiative in 2006. ${ }^{74,75}$ Notably, this first example only targeted 5 categories of snack foods, leading WTO Members to question its rationale in light of the objective of improving nutrition; such uneven or incomplete coverage, at the same time as altering the conditions of competition, is an indication that the policy in question may not be the most effective means to address the country's nutrition objectives. However, extensive lists of concerns have consistently been raised against the more comprehensive labelling policies that followed. None has progressed to formal disputes, but outcomes have ranged from policy being preserved (in Peru, Ecuador, Chile, Bolivia, Mexico and South Korea), to modified/compromised (in
Thailand), or significantly delayed (in Indonesia) (Table 2). Discussion of STCs raised regarding Uruguay's proposed nutrition warning labels was ongoing at the time of analysis.

Aside from an EC Treaty dispute process initiated against Denmark's ban on trans fatty acids (TFAs) that was later dropped, ${ }^{67}$ there appear to be no trade- or investmentrelated challenges to nutrient composition regulations through mandatory TFA or sodium reduction policies. ${ }^{52}$ In 2019, the Kingdom of Saudi Arabia announced a plan to impose a maximum limit on added sugar for all food and beverages. This was subject to a number of STCs, including its deviation from international standards, transparency and time to adapt, being more trade restrictive than necessary, insufficient scientific evidence, and questioning its rationale and legitimacy. ${ }^{100,101}$ The representative of Saudi Arabia promptly clarified that this proposal would be under review until further notice, and the STC discussions were ongoing at the time of analysis.

There is evidence of trade-related arguments being raised against emerging advertising restrictions in Chile, ${ }^{93,94}$ though no concerns have been raised in formal dispute channels such as the WTO TRIPS Council to date. No challenges have been raised to procurement policies for public health nutrition to date.

The findings from the literature reviewed are presented here, in the form of a revised conceptual framework (Figure 3). In terms of mechanisms: the data collected indicates that TIAs constrain policy space substantively and procedurally directly through rules and principles (non- discrimination, necessity, international standards, transparency, intellectual property, expropriation, fair and equitable treatment, and investor-state dispute settlement [ISDS]), and indirectly via their interaction with policy design factors (objectives framed, products/ services affected, nutrient thresholds chosen, formats, and time given to comment or implement). This policy space is also indirectly influenced through the interpretation and use of TIA text, by the various actors involved, which is related to their power, resources and capacity. Relevant actors and institutions include Member governments and their various ministries, industry stakeholders, TIA governing bodies, as well as civil society and the media. Likewise, domestic and regional regulatory contexts can have a moderating effect on whether or not mechanisms of influence are activated.

\section{Mechanisms}

Direct Trade and Investment Agreement Mechanisms

Most of the literature reviewed described direct mechanisms of TIA influence on policy space in terms of the text within agreements. A majority of the reviewed literature (17/26 of the academic and grey literature, and all but one case) on policy space for priority nutrition policies to prevent NCDs discuss the implications of rules on trade (rather than investment). Trade-focused literature covered WTO and/or regional or bilateral free TIAs (which we use hereinafter to distinguish from WTO trade agreements and investment agreements), but most heavily focusing on WTO agreements (eg, GATT, TBT, TRIPS). Seven of the academic papers were concerned with more recently developed bilateral and multilateral free 


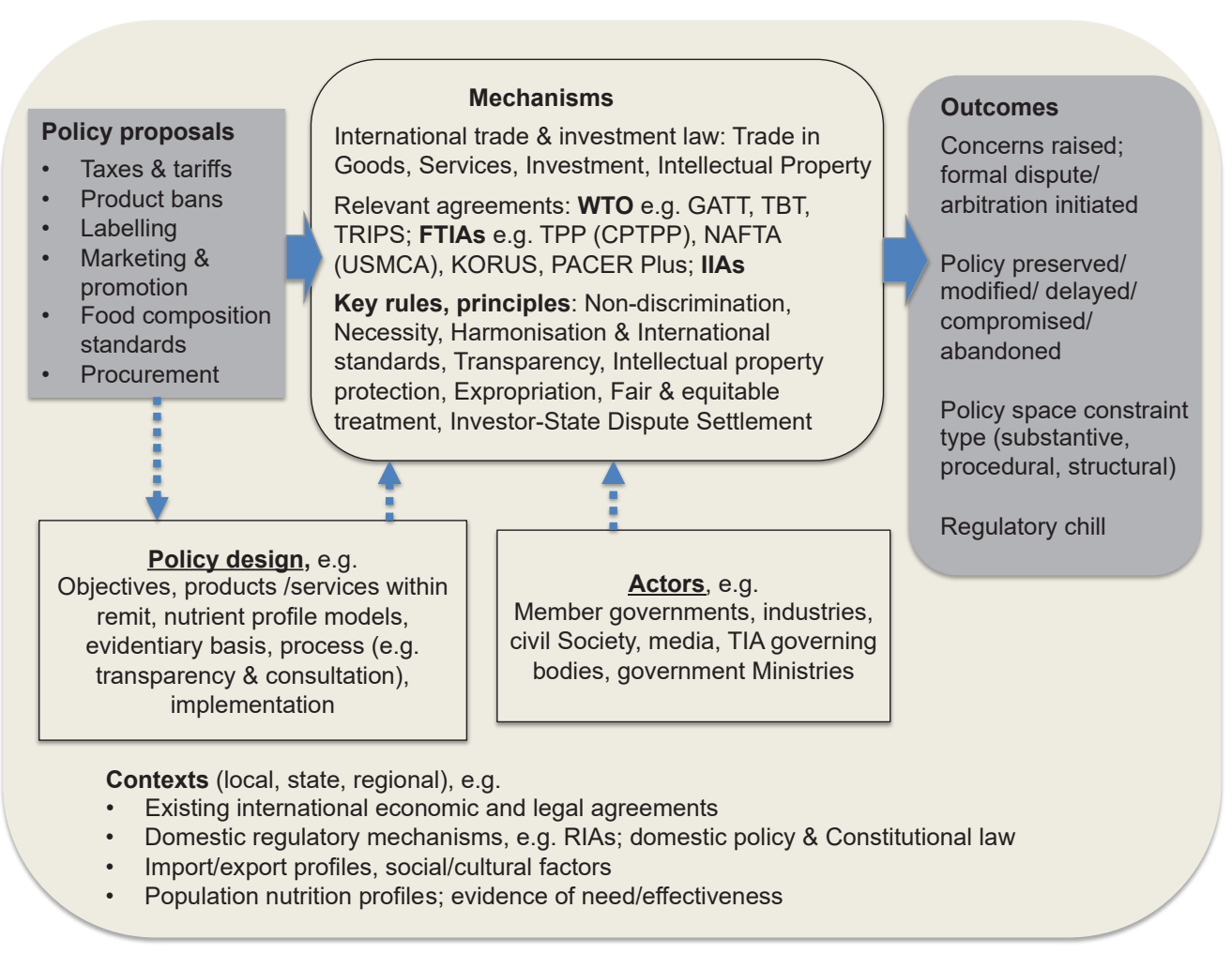

Figure 3. Revised Conceptual Framework for the Influence of International TIAs on Policy Space for Food Environment Regulations. Legend: Solid arrows indicate direct mechanisms, and dotted arrows show indirect mechanisms of influence. Abbreviations: TIA, trade and investment agreement; WTO, World Trade Organization; TBT, technical barriers to trade; GATT, General Agreement on Tariffs and Trade; RIAs, regulatory impact assessments; TRIPS, Trade-Related Aspects of Intellectual Property Rights; TPP, Trans-Pacific Partnership; KORUS, Korea Free Trade Agreement; NAFTA, North American Free Trade Agreement; FTIAs, free trade and investment agreements; CPTPP, Comprehensive and Progressive Agreement on Trans-Pacific Partnership; USMCA, United States Mexico Canada Agreement; IIAs, international investment agreement.

TIAs, that go beyond WTO obligations (which we refer to as WTO+). These included NAFTA, the TPPA, KORUS, PACER Plus, and the EC Treaty ${ }^{[2]}$. Investment law was less frequently discussed, with only 3 academic sources focussing on investment agreements specifically. The international investment landscape involves a complex web of thousands of bilateral investment treaties. It is also increasingly intertwined with multilateral WTO+ trade agreements, most of which will include a chapter on investment protections. Thus, the findings related to investment mechanisms presented here are by no means complete, exhaustive, nor up-to-date. It is important to note that there are also new agreements and new exceptions in some of the WTO+ agreements that were not present in the data collected.

This review indicated that the TIA rules and principles that may present direct mechanisms of constraint to policies seeking to improve food environments to prevent NCDs include non-discrimination, necessity, harmonisation/ adherence to international standards, transparency/ notification, regulatory coherence, intellectual property rights, (indirect) expropriation, fair and equitable treatment, and ISDS (see Table 3). We have described these as generally as possible, and it is important to note that the rules, definitions, clarifications and exceptions associated with these general principles will differ from one agreement to another, and may be especially different in recent TIAs.

Many of these key rules could apply to a broad range of policy scenarios. For example, any policy that establishes technical regulations (eg, nutrition labelling, packaging, product reformulation targets, or even some restrictions on advertising that may apply to goods) could arguably fall under the WTO TBT Agreement and TBT chapters of other TIAs, or be measures that affect the supply of a 'service' under trade in services agreements. Similarly, the rules surrounding the protection of investments (such as fair and equitable treatment of investors) are likely to be applicable, to some extent, to all of the policy areas of focus in this study. The same policy could therefore be affected by multiple chapters across multiple agreements that do not all have identical provisions.

The findings of this review indicate that rules on nondiscrimination, necessity, harmonisation, intellectual property, expropriation, and fair and equitable treatment present potential substantive constriction on nutrition policy space. The evidence found in this review suggest that formal appeals to these rules have mainly constrained poor policy design to date. For instance, incomplete coverage of products triggering discrimination concerns, or policy settings not well aligned with the stated public health objectives being subject to concerns around necessity (eg, the Mexican non-sugar sweetener tax, Thailand's front-of-pack labelling scheme on 5 categories of snack foods, or Samoa's turkey tail import ban).

On the other hand, this review indicates that necessity, harmonisation, transparency/notification, regulatory coherence, fair and equitable treatment, and ISDS rules present a procedural (policy process) form of constriction. Necessity rules entail a burden of proof that a measure is not more trade 
Table 3. Mechanisms of Influence on Nutrition Policy Space Related to Agreements

\begin{tabular}{|c|c|c|c|c|}
\hline $\begin{array}{l}\text { Principle/Mechanism } \\
\text { and Related Agreements }\end{array}$ & $\begin{array}{l}\text { Articles and Exceptions } \\
\text { Documented in Literature }\end{array}$ & Type(s) of Constraint and Description/Summary & Moderating Factors & $\begin{array}{l}\text { Relevant } \\
\text { Policy Area(s) }\end{array}$ \\
\hline $\begin{array}{l}\text { Non-discrimination } \\
\text { MFN and National } \\
\text { Treatment } \\
\text { Found in: } \\
\text { WTO: GATT, GATS, TBT, SPS; } \\
\text { FTIAs; } \\
\text { IIAs }\end{array}$ & $\begin{array}{l}\text { WTO: } \\
\text { GATT Art. } 1.1 \text { (MFN), Art. } 3.2 \\
\text { \& } 3.4 \text { (NT), General exception } \\
\text { XX(b) and Chapeau; } \\
\text { TBT Art. 2.1; } \\
\text { SPS Art. 5.5 }\end{array}$ & $\begin{array}{l}\text { Substantive constraint. } \\
\text { Foreign products/services/investments should receive treatment no less favourable than } \\
\text { 'like' products/services/investments of domestic origin or like circumstances - both in } \\
\text { intent and in effect. } \\
\text { The GATT provides for exceptions to some rules where policy is necessary to protect human, } \\
\text { animal or plant life or healtha, with a Chapeau that specifies: as long as measures are not } \\
\text { applied arbitrarily/unjustified discrimination and not hidden protectionism. }{ }^{49-51,53,59,62} \text { Non- } \\
\text { discrimination in GATS is similar to GATT and TBT obligations. }{ }^{60}\end{array}$ & $\begin{array}{l}\text { - Products, services and investments within } \\
\text { remit of agreement. } \\
\text { Products, services and investments within } \\
\text { remit of the regulation, ie, do any similar } \\
\text { products exist on the market, which are not } \\
\text { subject to regulation. } \\
\text { Determination of 'like' products or } \\
\text { circumstances. } \\
\text { - Any exceptions or explicit health protections. }\end{array}$ & All \\
\hline $\begin{array}{l}\text { Necessity } \\
\text { Found in: } \\
\text { WTO: GATT, TBT, GATS; } \\
\text { FTIAs }\end{array}$ & $\begin{array}{l}\text { WTO: } \\
\text { GATT Gen. exception XX(b); } \\
\text { TBT Art. } 2.2 \text {; } \\
\text { GATS Art. } 14\end{array}$ & $\begin{array}{l}\text { Substantive \& Process constraints. } \\
\text { Policy must be the least trade restrictive measure available to achieve a legitimate desired } \\
\text { objective (such as health protection or to ensure quality of a service) }{ }^{49,50,59,75,93} \text { Evidence is } \\
\text { required to justify. } \\
\text { For services: Additional disciplines may apply; for example, that any Technical standards } \\
\text { should be: based on objective and transparent criteria, not more burdensome than } \\
\text { necessary to ensure the quality of the service, and not in themselves a restriction on the } \\
\text { supply of a service. }\end{array}$ & $\begin{array}{l}\text { - Availability and quality of evidence justifying } \\
\text { need and projected effectiveness in achieving } \\
\text { desired objective. } \\
\text { - } \quad \text { raming of policy objectives. } \\
\text { Under GATS this depends upon specifically- } \\
\text { listed service sectors (which often include } \\
\text { Advertising through Audio-visual services). }\end{array}$ & All \\
\hline $\begin{array}{l}\text { Harmonisation and } \\
\text { International standards } \\
\text { Found in: } \\
\text { WTO: TBT; } \\
\text { FTIAs: TBT chapters }\end{array}$ & $\begin{array}{l}\text { WTO: } \\
\text { TBT Art. } 2.4\end{array}$ & $\begin{array}{l}\text { Substantive and process constraints. } \\
\text { Where an international standard exists, it should be applied as basis for regulation, except } \\
\text { if it would be ineffective or inappropriate to do so. Codex Alimentarius is recognised as a } \\
\text { relevant international standard for food. }\end{array}$ & $\begin{array}{l}\text { - Definition of what constitutes an international } \\
\text { standard. For example, under TBT, this must } \\
\text { include 'open membership,' disqualifying } \\
\text { WHO. } \\
\text { - } \quad \text { Codex Alimentarius guidelines. } \\
\text { Recognition of WHO recommendations as } \\
\text { complement/alternative to Codex. }\end{array}$ & $\begin{array}{l}\text { Labelling, } \\
\text { Nutrient } \\
\text { composition, } \\
\text { Advertising } \\
\text { restrictions }\end{array}$ \\
\hline $\begin{array}{l}\text { Transparency/Notification } \\
\text { Found in: } \\
\text { WTO: TBT, GATS; FTIAs: } \\
\text { Transparency chapters }\end{array}$ & $\begin{array}{l}\text { WTO: } \\
\text { TBT Art. 2.9; } \\
\text { GATS Art. 3; } \\
\text { TPPA/CPTPP transparency } \\
\text { chapter; } \\
\text { KORUS Art. } 9.6\end{array}$ & $\begin{array}{l}\text { Process constraint. } \\
\text { If a measure does not follow international standards (or no relevant standard exists), } \\
\text { members must notify others, provide information and allow time for comment (WTO TBT). } \\
\text { Governments must promptly publish any policy changes affecting trade in services } \\
\text { (GATS). }{ }^{59} \text { Deviations from WTO rules may ratchet-up these responsibilities, making them } \\
\text { more onerous for governments and providing greater rights to industry stakeholders. } \\
\text { Corporations may be better equipped to oppose any proposed nutrition policy. }{ }^{56,57} \text { The } \\
\text { TPPA/CPTPP goes beyond WTO rules, requiring prior stakeholder consultation. This } \\
\text { generally involves requirements to provide notice and publish information about policy } \\
\text { and administrative changes. }\end{array}$ & $\begin{array}{l}\text { Specific wording of disciplines, for instance the } \\
\text { definition of 'stakeholders' or 'interested persons.' } \\
\text { For example: KORUS text on transparency regarding } \\
\text { TBT required Parties to allow stakeholders (individual } \\
\text { or corporate) of the other party to participate in the } \\
\text { development of standards, technical regulations } \\
\text { and conformity assessment procedures. }{ }^{57} \text { This } \\
\text { introduces greater industry access into policy- } \\
\text { making processes. }\end{array}$ & All \\
\hline
\end{tabular}


Table 3. Continued

\begin{tabular}{|c|c|c|c|c|}
\hline $\begin{array}{l}\text { Principle/Mechanism } \\
\text { and Related Agreements }\end{array}$ & $\begin{array}{l}\text { Articles and Exceptions } \\
\text { Documented in Literature }\end{array}$ & Type(s) of Constraint and Description/Summary & Moderating Factors & $\begin{array}{l}\text { Relevant } \\
\text { Policy Area(s) }\end{array}$ \\
\hline $\begin{array}{l}\text { Regulatory coherence } \\
\text { Found in: } \\
\text { FTIAs: Regulatory coherence } \\
\text { chapters }\end{array}$ & $\begin{array}{l}\text { TPPA/CPTPP } \\
\text { Regulatory coherence chapter }\end{array}$ & $\begin{array}{l}\text { Process constraints. } \\
\text { Aims to streamline regulation across Member countries. This novel mechanism first } \\
\text { appeared in the TPPA/CPTPP, which prescribes consultation \& coordination mechanisms } \\
\text { that may require governments to provide opportunities for stakeholder input into policy- } \\
\text { making. Could further prescribe how regulations are developed at the domestic level, } \\
\text { including providing greater role and access for industry input. }{ }^{6,57}\end{array}$ & $\begin{array}{l}\text { Enforcement terms. For example, under the TPPA/ } \\
\text { CPTPP Regulatory Coherence principles cannot be } \\
\text { legally enforced, but rather are to be adhered to } \\
\text { in good faith. However, newer FTIAs such as the } \\
\text { USMCA do include enforcement mechanisms. }\end{array}$ & All \\
\hline $\begin{array}{l}\text { Intellectual property rights } \\
\text { Found in: } \\
\text { WTO: TRIPS; } \\
\text { FTIAs: IP chapters; } \\
\text { IIAs: IP chapters }\end{array}$ & $\begin{array}{l}\text { WTO: } \\
\text { TRIPS Art. 15; } \\
\text { TRIPS Art. 16; } \\
\text { TRIPS Art. 20; } \\
\text { TPPA/CPTPP IP chapter }\end{array}$ & $\begin{array}{l}\text { Substantive constraint. } \\
\text { The nature of goods or services should not be an obstacle to registration of a trademark } \\
\text { (TRIPS Art. 15). 'Unhealthiness' of a product or food service could therefore be interpreted } \\
\text { as not a valid reason to restrict the registration of a trademark. } \\
\text { Registered trademark owners have exclusive 'negative rights' to prevent its use by third } \\
\text { parties (TRIPS Art. 16), but this does not necessarily mean they have the 'positive right' to } \\
\text { use them. } .^{59,94} \\
\text { Trademarks should not be unjustifiably encumbered by special requirements (TRIPS } \\
\text { Art. 20). Thus, any policy seeking to restrict use or placement of brand names, logo, } \\
\text { licensed characters, or other distinguishing marks or design features would need proper } \\
\text { justification. } .^{59,93,94} \text { Health Impact Assessment of the TPPA (now replaced by the CPTPP) } \\
\text { indicated that it extended the protections of trademarks (eg, on packaging) beyond those } \\
\text { set out in TRIPS. }{ }^{56}\end{array}$ & $\begin{array}{l}\text { - Availability and quality of evidence justifying } \\
\text { need and projected effectiveness in achieving } \\
\text { desired objective. } \\
\text { - Framing of policy objectives. }\end{array}$ & $\begin{array}{l}\text { Labelling, } \\
\text { Advertising } \\
\text { restrictions }\end{array}$ \\
\hline $\begin{array}{l}\text { Expropriation (indirect) } \\
\text { Found in: } \\
\text { FTIAs: Investment chapters; } \\
\text { IIAs }\end{array}$ & $\begin{array}{l}\text { NAFTA Investment chapter } \\
\text { (Ch. 11); } \\
\text { TPPA/CPTPP Investment } \\
\text { chapter; } \\
\text { KORUS Investment chapter }\end{array}$ & $\begin{array}{l}\text { Substantive constraint. } \\
\text { Expropriation of an investment, even for a 'public purpose' and without discrimination, } \\
\text { may still warrant compensation. } \\
\text { One reviewed legal analysis of NAFTA indicated that a regulatory taking (ie, expropriation) } \\
\text { would have to be extreme in order for a claim of indirect expropriation to be upheld. }{ }^{55} \\
\text { However, precise wording in different investment agreements and chapters will vary, and } \\
\text { this has yet to play out in a dispute regarding nutrition policy. }\end{array}$ & $\begin{array}{l}\text { Detail of clarification. Newer TIAs may specify, } \\
\text { eg, the 'degree of impact on an investment' } \\
\text { and what constitutes non-discriminatory } \\
\text { actions, }{ }^{b} \text { but older BITs do not contain such } \\
\text { clarifications. } \\
\text { Definition of public health purpose. }{ }^{.} \text {Similarly, } \\
\text { newer agreements may include clearer } \\
\text { definitions. } \\
\text { Exceptions. General Exceptions do not } \\
\text { apply to this chapter in the TPPA/CPTPP for } \\
\text { example. }\end{array}$ & $\begin{array}{l}\text { All (especially } \\
\text { those involving } \\
\text { trademarks } \\
\text { (labelling, } \\
\text { advertising } \\
\text { restrictions) }\end{array}$ \\
\hline
\end{tabular}




\section{Substantive and process constraints.}

Its meaning is notoriously ambiguous and inconsistently interpreted, but this standard generally protects the 'legitimate expectations' of an investor of the regulatory

\section{Fair and Equitable}

Treatment

NAFTA Ch. 11;

Found in: $\quad$ TPPA/CPTPP Investment

FTIAs: Investment chapters; chapter

IIAs

\section{ISDS}

FTIAs: Investment chapters

(some)

NAFTA Ch. 11;

PPA/CPTPP Investment

chapter;

KORUS Investment chapter environment. Thow and McGrady ${ }^{61}$ interpret that investors have no right to expect the regulatory environment to remain unchanged, but if a host induces investment and later introduces a policy that regulates the products of that investment, this challenge could be applied. However, precise wording in different investment agreements and chapters will vary, and this has yet to play out in a dispute regarding nutrition policy.

\section{Process constraint.}

Allows investors to directly challenge government policy, rather than appealing to their host government to do so. Awards for compensation can include projected loss of future profits and compound interest. Investor-state arbitration processes have been criticized for being non-transparent, for lacking some of the safeguards of domestic legal processes, and for failing to consider broader issues related to public policy. ${ }^{57}$ The composition of dispute settlement tribunals ( 3 private sector lawyers) has raised concerns of bias toward industry interests. ${ }^{57}$
- Interpretations of 'legitimate expectations.' For example, this may include previous promises made pertaining to regulatory environment, incentives given or contractual commitments made, ${ }^{61}$ though this is not necessarily required for an award to be made.

- Clarification of the definition and scope of fair and equitable treatment within agreements.

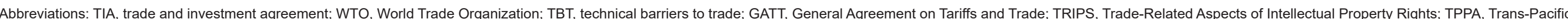

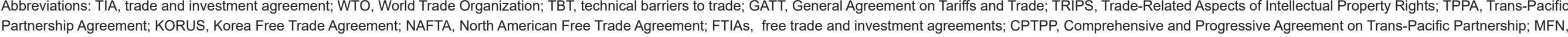

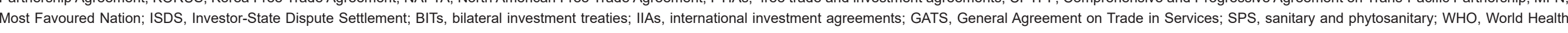
Organization; USMCA, United States Mexico Canada Agreement.

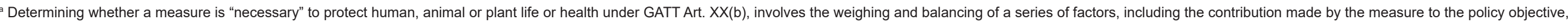
the importance of the common interests or values protected by the policy measure, and the impact of the measure on international trade. ${ }^{102}$

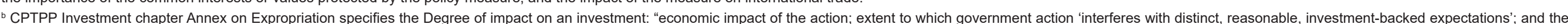

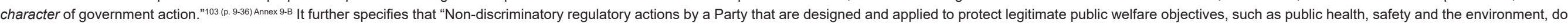

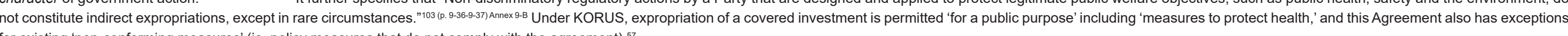
for existing 'non-conforming measures' (ie, policy measures that do not comply with the agreement). ${ }^{57}$

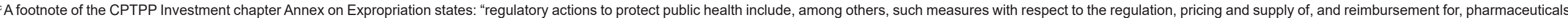

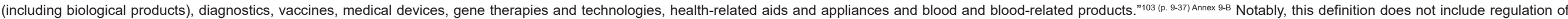
food for public health nutrition. 
restrictive than necessary; governments must come up with a body of evidence to back their decisions, or choose a less restrictive option. Harmonisation and standardisation rules likewise require justification of any technical regulation that deviates from an established international standard (such as the Codex Alimentarius), or in cases where such a standard does not exist. Transparency and notification rules provide the opportunity for further input into the policy-making process from industry stakeholders, thereby introducing the potential for both procedural and structural constriction of policy space. This input may be established directly, as in the case of the TPPA (now replaced with the Comprehensive and Progressive Agreement on Trans-Pacific Partnership, CPTPP) and KORUS, or indirectly through their respective government representatives (eg, at TBT Committee meetings). Regulatory coherence introduces new norms into the policymaking process, which may include stakeholder consultation and involvement as part of consultation and coordination mechanisms-again, introducing the potential for procedural and structural policy space constriction (though not legally enforceable under the TPPA/CTTP). Investors may take advantage of ambiguous fair and equitable treatment standards to pursue claims against food environment regulations, and may do so even more easily through ISDS mechanisms.

\section{Indirect Mechanisms}

The studies and cases in this review indicate that binding TIA rules can be understood as directly constraining policy space for food environment regulations, but that these constraints occur via their interaction with policy design factors. This policy space is also indirectly influenced through the interpretation and use of TIA text, by the various actors involved.

\section{Policy Design}

This review found that policy design elements with the potential to influence policy space through interaction with trade rules include: the framing of objectives, choice of products/services affected or nutrient profiles used, and the scientific basis and evidence used to justify technical regulations. As noted previously, shortcomings in policy design were associated with nutrition policies in Mexico, Thailand and Samoa that were constrained via TIA mechanisms. Trade database records for at least 3 cases (Ecuador, Chile and Saudi Arabia) showed that factors related to ease and cost of implementation may also trigger STCs in terms of regulations being overly 'burdensome.' The sources reviewed indicate that, generally, strategic policy design in these areas can limit substantive TIA constraints.

Two studies ${ }^{57,75}$ suggested that policy design process factors of following 'good regulatory practice' are related to procedural constriction of nutrition policy space. Failure to notify (and in some cases, engage) trade partners and investors of regulatory proposals, and with sufficient lead time, may be flagged as a violation of TIA commitments in terms of transparency and early notification, as was the claim in 7 of the 10 STC cases we reviewed. Such notification and engagement, however, introduces greater potential (and time) for a wide range of stakeholders to influence policy, effectively using TIAs to serve their own interests.

'Good regulatory practice' also implies evidence-based policy design, with justification for necessity, and projected effectiveness in achieving desired policy objectives. Analysis of the literature on TIAs and nutrition policy space raises the question: how much justifying evidence is enough? In the context of Indonesia, proposed mandatory labelling (including warning labels) for sugar, fat and sodium content on processed and fast foods to better inform consumers about nutrition and prevent NCDs was met with STCs from several members between 2013 and 2016, questioning the scientific justification and urging consideration of alternative approaches. ${ }^{76,82-92}$ It was announced that the policy would be delayed 4 years while the government considered alternate approaches, but no update was evident at the time of analysis. The labelling requirements, however, were based on the Balance Nutrition Guidelines and related 2008 WHO recommendations, as well as data from a 2014 nutrition survey conducted by the Ministry of Health. ${ }^{75}$

\section{Application and Interpretations of TIA Text}

Two studies highlighted the ways in which TIAs as structural instruments are used and interpreted to raise concerns or launch disputes, or to respond to them, constituting another indirect mechanism of constraint to policy space. Such indirect constraints relate to the power dynamics between actors involved, and their capacity to influence outcomes.

Barlow et $\mathrm{al}^{76}$ found that power asymmetries exist between the countries raising STCs in the TBT Committee and those responding to them, indicating that countries may use this forum as a means to exert and translate such power asymmetries into policy leverage. Wealthier nations (and companies in the case of ISDS) may have greater legal capacity to find 'loopholes' within agreements and use them to their advantage. The authors observed that more than 3 quarters (77.4\%) of STC challenges raised against low- and lowermiddle-income countries for NCD prevention regulations had been raised by wealthier nations. ${ }^{76}$ Another study reported that power imbalance between small Pacific Island Countries (PICs) and larger trading partners was a perceived factor constraining nutrition policy space: both in terms of influencing small PICs to enter into agreements to begin with (eg, through aid-dependency), and through the formal avenues of influence thereafter (eg, WTO rules limiting PICs' ability to restrict imports for public health reasons). ${ }^{78}$

Background literature suggested that indirect mechanisms of constraint on policy space for food environment regulation may play out even earlier in the policy cycle, for example through the domestic RIA process mentioned previously, though such a phenomenon was not reported in the data reviewed. The interpretations of trade ministries of how nutrition policy proposals would interact with trade commitments, including the lobbying of industry stakeholders to this effect, may contribute to whether or not policy moves forward to the notification stage, in which instance it would not appear as a potential case. 


\section{Contextual Factors}

This review indicated that contextual factors potentially influencing TIA-related nutrition policy space include the actors and institutions operating in trade and nutrition policy spheres, as well as national political and regulatory contexts.

\section{Actors and Institutions}

Actors may use several mechanisms to influence outcomes in their favour either directly or indirectly (eg, through the use of institutions), visibly or invisibly. ${ }^{104}$ This review found evidence that actors and institutional structures at both the international and national level can influence policy agendas, the power to engage in disputes, and the interpretation of evidence. Particularly relevant are government ministries, civil society organisations, food industry structure and power, consumer groups, dispute settlement bodies, and standards setting bodies.

Government departments (eg, ministries of health, trade, economy) are the principal environment in which policy is proposed and developed, and where regulatory chill occurs or does not. Five reviewed studies reported that the involvement of a broad collection of government actors (within both trade and health sectors) in agenda setting and policy development can be a supportive factor for nutrition policy space. . $2,75,95,105,106$ For instance, early engagement with trade policy-makers can help to identify any easily resolvable trade concerns before the notification stage. ${ }^{75}$ The outcome of such engagement hinges, however, on the overall support for regulation from within the trade departments, and the type of government in power and their ideological leaning (eg, in favour of more or less government intervention in markets). ${ }^{55,57}$ The engagement of civil society organisations can also contribute to the constriction or opening of policy space for public health nutrition through applied pressure for regulation and holding governments accountable. ${ }^{57,95}$ Public support for regulation was found to have supported positive policy space outcomes for nutrition regulations in Ghana and Denmark, ${ }^{62,67}$ to which media attention can make a strong contribution. ${ }^{67}$ Consumer-citizen activism may counter-balance corporate influence into the regulatory process and help to legitimise non-discriminatory policies made in good faith for public purposes such as NCD prevention ${ }^{55}$ - but only when these debates happen publicly. Trade partners may also influence governments' nutrition policy space invisibly through bilateral political relationships such as international aid, ${ }^{78}$ as might investors through contribution to gross domestic product. . $^{57,61}$

Food and beverage companies form a powerful interest group with a number of avenues of influence (direct, indirect, and invisible). The review indicated that the types of food industry present within a regulating country, their level of vertical investment ${ }^{61}$ and contribution to the economy, and the existing capacity of industry to engage in political processes can shape the policy space for public health nutrition. ${ }^{57}$ Commercial stakeholders may try to leverage their economic power directly by lobbying governments. Through submissions to governments during the TPPA negotiation process, for example, we know that food and beverage industry groups actively sought to shape the content of the Agreement (pushing for increased market access for processed foods, greater regulatory harmonisation, enhanced investment protection and legal remedies), particularly regarding SPS and TBT sections. ${ }^{58}$ TNCs can also exert invisible influence on nutrition policy space, for example through major contribution to employment and thus being a priority for government. ${ }^{51,55,57}$ We can infer that the stronger the industry-in terms of significance to the domestic (including export) economy and its size and lobbying power-the more likely governments may be to fight for that industry's position in agreement negotiation. Finally, this review suggests that TNCs are able to influence nutrition policy space indirectly through strategic engagement with the institutions involved in TIA governance.

The institutions involved in setting the 'rules of the game,' including dispute-settlement and standards-setting bodies, have the formal authority written into Agreements to influence policy space, and the extent of this influence is both visible and invisible. WTO bodies' proceedings are transparent (with the Appellate Body providing a means of appeal to decision-making), but many WTO+ dispute settlement bodies are not. Given their position of influence, the system of investment dispute arbitration panels has been criticised for lack of transparency and potential bias towards private sector interests, in particular due to the composition of these panels ( 3 private sector lawyers). ${ }^{57}$ The Codex Alimentarius Commission (Codex) jointly established by the United Nations Food and Agriculture Organization and the WHO is widely recognised as the body deemed appropriate for producing 'relevant international standards' for food and beverages, especially within the realm of food safety. For instance, Codex standards were referenced by Member representatives in each of the cases we reviewed regarding nutrition labelling. It is widely known, however, that the Codex Commission's membership structure allows Member country delegates to invite industry representatives, and includes 'non-government organisation' Observers of which industry groups make up a large proportion. ${ }^{95,107}$ Commercial influence in this forum, eg, influencing the standards at Codex that are then used to interpret and determine necessity under TIAs, is essentially 'mobilising the bias' present in these institutions toward economic interests, to influence policy space in their favour. ${ }^{104}$

\section{Political and Regulatory Contexts}

This review identified several national political and regulatory factors that may influence nutrition policy space in different ways (Table 4). We found that national regulatory factors with potential to influence interpretations of policy proposals with respect to TIA rules included: availability and quality of evidence (associated with research capacity and budget), which may influence interpretations of necessity and justification ${ }^{50,62,67,75}$; regulatory frameworks (eg, being part of a comprehensive suite of interventions), which may also influence interpretations of justification ${ }^{50,54,59,75,77,95}$; and history of regulation, which may influence interpretations of 'good faith', necessity, and fair and equitable treatment. ${ }^{61,62,67}$

The literature reviewed suggested 3 national stakeholder 
Table 4. Political and Regulatory Context Factors Identified in Review

\section{National Regulatory Factors that Potentially Influence Interpretations of Policy Proposals with Respect to TIA Rules}

Availability and quality of

evidence

Regulatory framework

istory of regulation

Influences interpretations of necessity and justification. This includes data on their stage in the nutrition transition, burden (or double/triple burden) of malnutrition, and clear need to address dietrelated $\mathrm{NCD}^{62}$ as well as strong evidence of the health risks associated with consumption of products to be regulated, ${ }^{50,67}$ and projected effectiveness of the proposed measure in achieving the objective of improving diets and preventing NCDs. ${ }^{75}$ WTO TBT Members questioned the scientific evidence backing the policy in half (5/10) of the STC cases reviewed.

May influence interpretations of justification. Six studies reported that a policy measure may be more robustly defensible if it is part of a comprehensive suite of interventions, including less trade restrictive alternatives such as public education campaigns (mitigating the argument that less trade restrictive alternatives are available). $50,54,59,75,77,95$

Can influence interpretations of good faith, necessity, and fair and equitable treatment. Long-standing history of food regulation in Ghana may have supported policy space for Ghana's import standards on fatty meats, by setting a precedent for further nutrition regulations. ${ }^{62}$ Denmark's TFA ban may have had more policy space because the measure started out as a voluntary agreement, in terms of having evidence to show that voluntary measures had been insufficient to achieve desired public health objectives. ${ }^{67}$ Domestic conditions surrounding incentives and contractual commitments previously given to the private sector may affect nutrition policy space with respect to investment agreements, as these may serve to establish investors' 'legitimate expectations' of the regulatory environment. ${ }^{61}$

\section{National Stakeholder Factors that Potentially Influence Power Dynamics and Capacity to Influence Policy Space}

Party to which agreements, and with whom

Economic stakeholder

landscape

Activity and influence of civil society
Power dynamics with trade partners influence governments' relative negotiating power, and relative capacity to mount or respond to a dispute. For instance, Fa'alili-Fidow et al78 suggested that PICs had a weaker trade bargaining position with respect to larger, wealthier neighbours on whom they rely for aid. Barlow et al ${ }^{76}$ noted that more than 3 quarters of the STCs raised against LMIC public health policies in the TBT Committee were by high-income countries.

The size and importance of different private sector stakeholders (including foreign direct investment) relate to the power of an industry within country to influence government to act (or to act on its own in the case of ISDS). ${ }^{55}$ Vertical investment in the food supply chain gives a company greater power within a country's food system, and increases the cumulative effect that a policy intervention may have on a given investor's interests and their motivation and capacity to contest it. ${ }^{61}$

The capacity and resources of civil society to engage in the policy process may influence regulatory chill. Having strong support from CSOs to advocate for health policy, generate supporting evidence, hold governments accountable, push for transparency in the policy process, and generally counter-balance industry influence, has the potential to reduce regulatory chill. $95,105,106$ Conversely, industry opposition tactics may include donating to CSOs to encourage them advocating against nutrition regulations such as marketing restrictions.
Capacity for inter-sectoral collaboration within

government

Financial and legal capacity within TNCs

\section{National Institutional Factors that Potentially Influence Policy Space and Regulatory Chill}

Three studies suggested that institutional structures enabling collaboration between trade and health sectors (eg, ministries or departments) in policy design could increase the capacity of governments to assess the legal basis or implications of any threats made, and reduce regulatory chill 62,75,95 Conversely, internal vetting processes for nutrition policy proposals in which trade and economic departments dominate may increase systemic regulatory chill. 36,57

TNCs' institutional capacity to engage in domestic health policy-making processes (eg, through lobbying) may contribute to regulatory chill.95 TNCs' capacity to engage in trade and investment dialogue and processes and to mount challenges may constrict nutrition policy space, and may increase regulatory chill in a normative sense if such challenges are successfully raised.

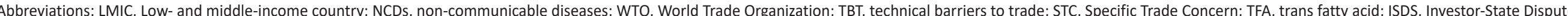
Settlement; TNCs, trans-national companies; CSOs, civil society organisations; PICs, Pacific Island Countries. 
factors that potentially influence power dynamics and capacity to influence policy space. Firstly, the set of Agreements a country is Party to, and with whom, including its power dynamics with these trade partners, may influence governments' relative negotiating power, and relative capacity to mount or respond to a dispute. ${ }^{76,78}$ Second, a country's economic landscape-and the associated size and importance of its various private sector stakeholders-relate to the power of industry stakeholders within country to influence government to act (or to act on their own in the case of ISDS). ${ }^{55,61}$ Third, the capacity and resources of civil society to advocate for health policy, generate supportive evidence and hold governments accountable may counter-balance industry opposition in policy-making processes, helping to reduce regulatory chill of nutrition policy proposals..$^{5,95,105,106}$

Finally, this review indicated two national institutional factors that potentially influence policy space and regulatory chill. Three studies suggested that institutional structures within government enabling collaboration between trade and health sectors in policy design could increase the capacity of governments to assess the legal basis or implications of any threats made, and reduce the potential for regulatory chill. ${ }^{62,75,95}$ Within the private sector, on the other hand, individual TNCs represent institutions with potentially strong financial and legal capacity to influence policy space. TNCs' institutional capacity to engage in domestic health policy making processes may contribute to regulatory chill, ${ }^{95}$ while their capacity to engage in trade and investment dialogue and processes, and to mount challenges, may constrict policyspace, and increase regulatory chill in a normative sense if challenges are successfully raised.

\section{Discussion}

This realist review has provided greater nuance to our understanding of the ways in which TIAs may constrain policy space for priority food environment regulations. The impact on policy outcomes has ranged from policy being essentially preserved (eg, TFA ban in Denmark, and nutrition labelling in Peru, Ecuador, Chile, Bolivia, Mexico and South Korea), to modified or compromised (eg, nutrition warning labels in Thailand), significantly delayed (eg, nutrition warning labels in Indonesia), or abandoned altogether (eg, the non-cane sugar sweetener tax in Mexico, and turkey tail ban in Samoa). In addition to specific threats or concerns raised in trade and investment forums, policymakers' knowledge and understanding of such constraints likely also contributes to domestic regulatory chill, though no empirical evidence was found to this effect. Most substantive constraints on policy space (ie, when trade or investment agreements directly limit the range of policy instruments available to governments) appear to be avoidable through strategic policy design. In this sense, our findings align with the perspective Crosbie, Carriedo and Schmidt published earlier this year urging governments not to be deterred by threats from TNC trade associations to pursue challenges to evidence-informed nutrition policies through the WTO and regional trade agreements. ${ }^{108}$ However, procedural constraints (ie, when the process of policy-making is limited or influenced) are often linked to the incursion of influence from private sector interests in policy-making, including selfserving interpretations and use of TIA rules, and appear to be far more insidious. Increasingly, 'good regulatory practice' entails conducting domestic RIAs of policy proposals by relevant ministries, including departments of trade. The new generation of TIAs increasingly codify the adherence to this type of approach to policy-making. This introduces greater potential for economic stakeholders to use and interpret TIAs to serve their own interests.

The potential influence of TIAs on policy space is different for each policy area. For instance, the evidence collected suggests that some fiscal policies (for a public health objective, if well designed and not discriminatory) appear to be compatible with trade and investment rules. Product import bans, on the other hand, are not viable under TIAs, especially if similar products exist domestically. No challenges have been raised against food procurement nutrition policies thus far. Challenges to mandatory nutrient limits/reformulation policy have been limited to date, but our findings indicate that limits on sodium or TFAs may be more viable than sugar content limits. Labelling (especially frontof-pack interpretive nutrition labelling) and restriction of advertising and marketing appear to have the greatest risk of trade- or investment-related challenges, especially in relation to emerging areas of regulating digital sales and marketing.

Overall, the available evidence indicates that robust policy design should create sufficient policy space for regulation to achieve healthy food environments without substantive constraints from TIAs. Procedural and indirect constraints are less visible and less certain, though a willing government cognisant of the principles underlying TIAs (such as nondiscrimination, necessity, etc) and thus their intersection with food system policies should be able to defend nutrition policies serving legitimate objectives.

However, this study also highlighted the power dynamics (including political capital, economic resources, and legal capacity to understand and interpret agreements) that shape how TIA texts are designed, used and interpreted. Four main dynamics stand out as contributing to policy space constraints in relation to food systems and nutrition. First, there is an underlying power asymmetry between Members in the negotiation and writing of TIAs. This has been observed, for example, from the perspective of PIC policy-makers in trade bargaining with their larger Pacific neighbours on whom they rely for aid. ${ }^{78}$ Second, power asymmetry exists between Members and between governments and commercial stakeholders in the interpretation and use of TIAs to further economic interests. This is both in terms of their respective resources and legal capacity to raise concerns, ${ }^{76}$ and their avenues of recourse to use TIAs as structural instruments. ${ }^{55,57,60}$ For instance, only foreign investors can challenge governments in ISDS, not vice versa, ${ }^{31}$ and TNCs have the option of forumshopping to find jurisdictions where their subsidiaries have most favourable trade and investment rights. Third, there is incursion of private sector interests in institutions governing trade and investment disputes, as well as standard setting. ${ }^{57}$ This dynamic is particularly visible in the context of standard 
setting at the Codex Alimentarius Commission. ${ }^{95,107}$ Fourth, the underlying asymmetry between the influence of Trade and other economic Ministries in relation to Health Ministries in the policy-making process contributes to systemic regulatory chill. $^{36}$

In line with global commentary on the agency that policymakers and negotiators have to shape agreements and develop mitigating policies to protect domestic policy space, ${ }^{31}$ this research indicates 4 opportunities to preserve policy space for public health nutrition objectives. First, while this review identified ISDS provisions as potential constraints to nutrition policy space, there is global concern regarding this inclusion that has led to formal global discussions of reform as well as reduced adoption of these clauses. ${ }^{109,110}$ For example, the carveout for tobacco from the ISDS provisions in the CPTPP was carried over in a revised TIA between Australia and Singapore. This was subsequently significantly expanded in the Australia-Peru TIA to exclude health policy more generally from ISDS. These changes were brought about by pressure from health advocates and from governments reacting to claims over health policies, showing that this is in fact a dynamic negotiation where nutrition policy space could be regained in response to strategic nutrition advocacy. The current discontent with the international trade and investment architecture indicates a potential window for broad reform. ${ }^{111}$

Second, the procedural (policy process) constraints identified here suggest an opportunity to examine more closely the stages within the policy-making process at which it is appropriate that commercial stakeholders are consulted, such as in matters related to implementation. ${ }^{12}$ This also means clarifying consultation versus being at the policydevelopment table. Consultation guidelines should include management of commercial conflict of interest (which would involve careful scrutiny of industry-generated evidence and biased arguments). In addition, fair and equitable treatment clauses may more narrowly establish what legitimate expectations of investors are. For instance, in terms of transparency and consultation, it should be made clear that the scope of fair and equitable treatment does not include involvement in decision-making in line with government objectives to avoid conflict of interest. While the Framework Convention on Tobacco Control includes clear provisions regarding exclusion of the tobacco industry from tobacco control policy, demonstrating the feasibility of limits, such a hard-line approach is unlikely for regulating food and nonalcoholic beverages, as the nature of potential harm these products present is not so straightforward.

Third, this review has identified the inclusion of commitments to regulatory coherence as a cause for concern; although in many ways positive, they can be readily weaponised by powerful agents to force less powerful countries to cede policy space. This is particularly acute with broad commitments to regulatory coherence, for example, NAFTA was renegotiated to the United States Mexico Canada Agreement (USMCA) in 2019, with more far-reaching implications for regulatory coherence. ${ }^{113}$ This included heavy and enforceable regulatory coherence regulations, codifying the RIA-style, light-handed approach (presumption of self-regulating markets), as well as industry participation. Regulatory coherence and RIAs are being discussed in WTO plurilateral negotiations, relevant to both investment facilitation and domestic regulation disciplines. Governments wanting to preserve policy space for public health nutrition should avoid the USMCA approach of detailed, extensive and prescriptive commitments to regulatory coherence, and its use of binding language throughout. ${ }^{113}$

Fourth, the review indicated that international standards can either preserve or constrain policy space for nutrition depending on their quality, comprehensiveness and (freedom from) commercial conflict of interest. This suggests an opportunity to strengthen nutrition standards as international reference points, as well as their use for harmonising trade in goods. For example, if the current discussion on front of pack nutrition labelling at the Codex Commission results in a recommendation that supports strong and contextually relevant public health labelling, it could provide a strong justification for national labelling measures that are currently subject to STCs at the WTO. ${ }^{107,114}$ Finally, governments could routinely conduct Health Impact Assessments or Human Rights Impact Assessments for TIAs prior to or during the negotiation phase, ${ }^{56}$ which explicitly consider food environment policy space as part of a broader conception of the right to food security and nutrition.

\section{Strengths and Limitations}

The sources reviewed span 5 academic databases covering different disciplines, two institutional TIA databases, and grey literature from all of the major international organisations working in this area. The inclusion of specific search terms for each of the policy areas of focus allowed for more detailed evidence to be gathered. The main limitation of this study is its confinement to published material, which is slow to catch up with developments in the trade and investment space. In addition, this review's exclusive coverage of English language publications is another possible limitation. Policy innovation in these areas also still in relatively early stages, so there is a lack of empirical evidence of trade/investment barriers. Theoretical constraints (eg, in trade in services, which is largely missing in the literature but central to advertising and marketing restrictions) that might arise in the future have therefore been mostly left out.

This study also relies on transparency. Only the WTO makes publicly available its committee discussions and arbitration decisions. Much bilateral and regional negotiation happens behind closed doors. Furthermore, new agreements are constantly being negotiated (mostly in secret), so it is unclear what their potential implications may be for public health nutrition. We note that these agreements form a dynamic space. Recent agreements tend to impose greater constraints in areas such as TBT and SPS, as well as services, although many also include clarifications to safeguard public health.

\section{Conclusions}

This study examined the extent to which TIAs can and have constrained governments seeking to regulate their food environments. Available evidence suggests that there are 
potential TIA contributors to policy inertia on nutrition, but that strategic policy design can avoid most substantive constraints. However, process constraints in the name of good regulatory practice (in the form of ISDS provisions, transparency, regulatory coherence, fair and equitable treatment, and harmonisation) pose a more serious threat of reducing government policy space to enact healthy food policies. We found that the capacity and resources of relevant actors has a moderating effect on whether such policy space constriction occurs or not (ie, whether TIA mechanisms of constraint are activated), and that there are opportunities for strategic action to mitigate potential impacts. This conceptual framework on how TIAs may constrain policy space for nutrition regulation can also provide insights relevant to measures for food system sustainability and other areas of public health.

\section{Acknowledgements}

The authors wish to acknowledge the comments given by Jane Kelsey on draft versions of this paper.

Ethical issues

Not applicable.

Competing interests

Authors declare that they have no competing interests.

\section{Authors' contributions}

All 3 authors contributed to study conception and design, analysis and interpretation of data, and critical revision of the manuscript. Acquisition of data and drafting of manuscript was done by KG. AMT and BS provided supervision.

\section{Authors' affiliations}

${ }^{1}$ School of Population Health, University of Auckland, Auckland, New Zealand. ${ }^{2}$ Menzies Centre for Health Policy, The University of Sydney, Sydney, NSW, Australia.

\section{Endnotes}

[1] Substantive constriction: Occurs when trade or investment agreements directly limit the range of policy instruments available to governments. Procedural constriction: Occurs when the process of policy-making is limited or influenced. This may include regulatory chill, when the potential threat of trade sanctions or costly litigation deters national governments from initiating policy processes. It may also include transparency/notification or regulatory coherence mechanisms that bring new international actors and institutions into the domestic policy-making process. Structural constriction: Occurs if trade and investment policy facilitates a shift from public to private provision of goods and services such that the economic and regulatory power of private sector actors is expanded.

[2] Notably, the first two of these agreements no longer exist: the NAFTA was renegotiated to the United States Mexico Canada Agreement (USMCA), and the TPPA never ratified but replaced with the Comprehensive and Progressive Agreement on Trans-Pacific Partnership (CPTPP) without United States' membership. The literature gathered did not include any in-depth analyses of either of these new agreements.

References

1. World Cancer Research Fund. Food, Nutrition, Physical Activity and the Prevention of Cancer: A Global Perspective. Washington, DC: American Institute for Cancer Research; 2007.

2. World Health Organization (WHO). Guideline: Sodium Intake for Adults and Children. Geneva: WHO; 2012.

3. Strazzullo P, D'Elia L, Kandala NB, Cappuccio FP. Salt intake, stroke, and cardiovascular disease: meta-analysis of prospective studies. BMJ. 2009;339:b4567. doi:10.1136/bmj.b4567

4. Mozaffarian D, Aro A, Willett WC. Health effects of trans-fatty acids: experimental and observational evidence. Eur J Clin Nutr. 2009;63 Suppl 2:S5-21. doi:10.1038/sj.ejcn.1602973
5. Johnson RK, Appel LJ, Brands M, et al. Dietary sugars intake and cardiovascular health: a scientific statement from the American Heart Association. Circulation. 2009;120(11):1011-1020. doi:10.1161/ circulationaha.109.192627

6. Sonestedt E, Overby NC, Laaksonen DE, Birgisdottir BE. Does high sugar consumption exacerbate cardiometabolic risk factors and increase the risk of type 2 diabetes and cardiovascular disease? Food Nutr Res. 2012;56. doi:10.3402/fnr.v56i0.19104

7. Te Morenga L, Mallard S, Mann J. Dietary sugars and body weight: systematic review and meta-analyses of randomised controlled trials and cohort studies. BMJ. 2013;346:e7492.

8. Mozaffarian D, Hao T, Rimm EB, Willett WC, Hu FB. Changes in diet and lifestyle and long-term weight gain in women and men. N Engl J Med. 2011;364(25):2392-2404. doi:10.1056/NEJMoa1014296

9. Malik VS, Willett WC, Hu FB. Sugar-sweetened beverages and BMI in children and adolescents: reanalyses of a meta-analysis. $\mathrm{Am} \mathrm{J}$ Clin Nutr. 2009;89(1):438-439; author reply 439-440. doi:10.3945/ ajcn.2008.26980

10. Baker P, Friel S, Schram A, Labonte R. Trade and investment liberalization, food systems change and highly processed food consumption: a natural experiment contrasting the soft-drink markets of Peru and Bolivia. Global Health. 2016;12(1):24. doi:10.1186/ s12992-016-0161-0

11. Schram A, Labonte R, Baker P, Friel S, Reeves A, Stuckler D. The role of trade and investment liberalization in the sugar-sweetened carbonated beverages market: a natural experiment contrasting Vietnam and the Philippines. Global Health. 2015;11(1):41. doi:10.1186/s12992-015-0127-7

12. Monteiro CA, Moubarac JC, Cannon G, Ng SW, Popkin B. Ultraprocessed products are becoming dominant in the global food system. Obes Rev. 2013;14 Suppl 2:21-28. doi:10.1111/obr.12107

13. Baker P, Friel S. Food systems transformations, ultra-processed food markets and the nutrition transition in Asia. Global Health. 2016;12(1):80. doi:10.1186/s12992-016-0223-3

14. Moodie R, Stuckler D, Monteiro C, et al. Profits and pandemics: prevention of harmful effects of tobacco, alcohol, and ultra-processed food and drink industries. Lancet. 2013;381(9867):670-679. doi:10.1016/s0140-6736(12)62089-3

15. Worldwide trends in body-mass index, underweight, overweight, and obesity from 1975 to 2016: a pooled analysis of 2416 populationbased measurement studies in 128.9 million children, adolescents, and adults. Lancet. 2017;390(10113):2627-2642. doi:10.1016/s01406736(17)32129-3

16. Afshin A, Forouzanfar MH, Reitsma MB, et al. Health effects of overweight and obesity in 195 countries over 25 years. N Engl J Med. 2017;377(1):13-27. doi:10.1056/NEJMoa1614362

17. An R, Guan C, Liu J, Chen N, Clarke C. Trade openness and the obesity epidemic: a cross-national study of 175 countries during 1975-2016. Ann Epidemiol. 2019;37:31-36. doi:10.1016/j. annepidem.2019.07.002

18. De Vogli R, Kouvonen A, Gimeno D. The influence of market deregulation on fast food consumption and body mass index: a crossnational time series analysis. Bull World Health Organ. 2014;92(2):99107a. doi:10.2471/blt.13.120287

19. Popkin BM, Corvalan C, Grummer-Strawn LM. Dynamics of the double burden of malnutrition and the changing nutrition reality. Lancet. 2020;395(10217):65-74. doi:10.1016/s0140-6736(19)324973

20. Worldwide trends in diabetes since 1980: a pooled analysis of 751 population-based studies with 4.4 million participants. Lancet. 2016;387(10027):1513-1530. doi:10.1016/s0140-6736(16)00618-8

21. Swinburn BA, Kraak VI, Allender S, et al. The global syndemic of obesity, undernutrition, and climate change: the Lancet Commission report. Lancet. 2019;393(10173):791-846. doi:10.1016/s01406736(18)32822-8

22. World Health Organization (WHO). Global Action Plan for the Prevention and Control of NCDs 2013-2020. Geneva: WHO; 2013:103.

23. World Health Organization (WHO). Report of the Commission on Ending Childhood Obesity. Geneva: WHO; 2016:50.

24. World Health Organization (WHO). Tackling NCDs: 'Best Buys' and 
Other Recommended Interventions for the Prevention and Control of Noncommunicable Diseases. Geneva: WHO; 2017:28.

25. Roberto CA, Swinburn B, Hawkes C, et al. Patchy progress on obesity prevention: emerging examples, entrenched barriers, and new thinking. Lancet. 2015;385(9985):2400-2409. doi:10.1016/s01406736(14)61744-x

26. Popkin B, Monteiro C, Swinburn B. Overview: Bellagio conference on program and policy options for preventing obesity in the lowand middle-income countries. Obes Rev. 2013;14 Suppl 2:1-8. doi:10.1111/obr.12108

27. Dr. Margaret Chan, Director-General of the World Health Organization. Opening address at the 8th Global Conference on Health Promotion. Presented at: the 8th Global Conference on Health Promotion; June 10, 2013; Helsinki, Finland. https://www.who.int/dg/speeches/2013/ health_promotion_20130610/en/.

28. McNeill D, Barlow P, Birbeck C, et al. Trade and investment agreements: implications for health protection. I World Trade. 2017;51(1):159-182.

29. Barlow P, McKee M, Basu S, Stuckler D. The health impact of trade and investment agreements: a quantitative systematic review and network co-citation analysis. Global Health. 2017;13(1):13. doi:10.1186/s12992-017-0240-x

30. Koivusalo M, Schrecker T, Labonté R. Globalization and policy space for health and social determinants of health. In: Labonte R, Schrecker T, Packer C, Runnels V, eds. Globalization and Health: Pathways, Evidence and Policy. Routledge; 2009:105-130.

31. Rodrik D. What do trade agreements really do? J Econ Perspect. 2018;32(2):73-90. doi:10.1257/jep.32.2.73

32. Voon T, Mitchell AD. Philip Morris vs. Tobacco Control: Two Wins for Public Health but Uncertainty Remains. Columbia FDI Perspectives. 2016;182:1-3

33. Hepburn J. Final Costs Details are Released in Philip Morris v. Australia Following Request by IAReporter. Investment Arbitration Reporter (online). https://www.iareporter.com/articles/final-costsdetails-are-released-in-philip-morris-v-australia-following-request-byiareporter/. Published March 21, 2019

34. Kelsey J. Regulatory chill: learnings from New Zealand's plain packaging tobacco law. QUT Law Rev. 2017;17(2):21-45. doi:10.5204/ qutlr.v17i2.701

35. Tienhaara K. Regulatory chill and the threat of arbitration: a view from political science. In: Brown C, Miles K, eds. Evolution in Investment Treaty Law and Arbitration. Cambridge University Press; 2011.

36. Van Harten G, Scott DN. Investment treaties and the internal vetting of regulatory proposals: a case study from Canada. J Int Dispute Settl. 2016;7(1):92-116. doi:10.1093/jnlids/idv031

37. Pawson R, Greenhalgh T, Harvey G, Walshe K. Realist review-a new method of systematic review designed for complex policy interventions. J Health Serv Res Policy. 2005;10 Suppl 1:21-34. doi:10.1258/1355819054308530

38. Baker $\mathrm{P}$, Hawkes $\mathrm{C}$, Wingrove $\mathrm{K}$, et al. What drives political commitment for nutrition? a review and framework synthesis to inform the United Nations Decade of Action on Nutrition. BMJ Glob Health. 2018;3(1):e000485. doi:10.1136/bmjgh-2017-000485

39. Farrell P, Thow AM, Abimbola S, Faruqui N, Negin J. How food insecurity could lead to obesity in LMICs: when not enough is too much: a realist review of how food insecurity could lead to obesity in low- and middle-income countries. Health Promot Int. 2018;33(5):812826. doi:10.1093/heapro/dax026

40. Wong G, Greenhalgh T, Westhorp G, Buckingham J, Pawson R. RAMESES publication standards: realist syntheses. BMC Med. 2013; 11(1):21. doi:10.1186/1741-7015-11-21

41. Wong G, Westhorp G, Pawson R. Realist synthesis: RAMESES training materials. https://www.ramesesproject.org/media/Realist_ reviews_training_materials.pdf. Published 2013.

42. Voon T, Mitchell AD, Liberman J. Regulating Tobacco, Alcohol and Unhealthy Foods: The Legal Issues. Routledge; 2014

43. Fidler DP, Aginam O, Correa C. Legal Review of the General Agreement on Trade in Services (GATS) from a Health Policy Perspective. WHO; 2006.

44. Schram A, Ruckert A, VanDuzer JA, et al. A conceptual framework for investigating the impacts of international trade and investment agreements on noncommunicable disease risk factors. Health Policy Plan. 2018;33(1):123-136. doi:10.1093/heapol/czx133

45. Kelsey J. International Trade Law and Tobacco Control: Trade and Investment Law Issues Relating to Proposed Tobacco Control Policies to Achieve an Effectively Smokefree New Zealand by 2025. Auckland, NZ: The University of Auckland; 2012:99.

46. Schram A, Friel S, VanDuzer JA, Ruckert A, Labonté R. Internalisation of international investment agreements in public policymaking: developing a conceptual framework of regulatory chill. Global Policy. 2018;9(2):193-202. doi:10.1111/1758-5899.12545

47. QSR International Pty Ltd. NVivo Qualitative Data Analysis Software.

48. Halabi SF. International trademark protection and global public health: a just-compensation regime for expropriations and regulatory takings. Cathol Univers Law Rev. 2012;61(1):325-380.

49. Sheargold E, Mitchell AD. Oils ain't oils: product labelling, palm oil and the WTO. Melb J Int Law. 2011;12:396-418.

50. McGrady B, Jones A. Tobacco control and beyond: the broader implications of United States Clove Cigarettes for noncommunicable diseases. Am J Law Med. 2013;39(2-3):265-289. doi:10.1177/009885881303900204

51. Marquez C. Warning: This Product May Cause Heart Disease, Diabetes, or Just Make You Fat: Using the International Strategy Requiring Warning Labels on Tobacco as a Blueprint for Regulating Soft Drinks. Southwest J Int Law. 2015;21:457-478.

52. Kaldor JC. Food reformulation for NCD-prevention: regulatory options and potential barriers. QUT Law Rev. 2018;18(1):76-95. doi:10.5204/ qutlr.v18i1.729

53. Larios P. The fight at the soda machine: analyzing the sweetener trade dispute between the United States and Mexico before the World Trade Organization. Am Univ Int Law Rev. 2004;20(3):649-702.

54. World Health Organization Regional Office for Europe. Evaluating Implementation of the WHO Set of Recommendations on the Marketing of Foods and Non-Alcoholic Beverages to Children: Progress, Challenges and Guidance for next Steps in the WHO European Region. WHO Regional Office for Europe; 2018.

55. Salazar ARV. NAFTA Chapter 11, regulatory expropriation, and domestic counter-advertising law. Ariz J Int Comp Law. 2010;27(1):3182.

56. Hirono K, Haigh F, Gleeson D, Harris P, Thow AM, Friel S. Is health impact assessment useful in the context of trade negotiations? a case study of the Trans Pacific Partnership Agreement. BMJ Open. 2016;6(4):e010339. doi:10.1136/bmjopen-2015-010339

57. Thow AM, Snowdon W, Labonté R, et al. Will the next generation of preferential trade and investment agreements undermine prevention of noncommunicable diseases? a prospective policy analysis of the Trans Pacific Partnership Agreement. Health Policy. 2015;119(1):8896. doi:10.1016/j.healthpol.2014.08.002

58. Friel S, Ponnamperuma S, Schram A, et al. Shaping the discourse: what has the food industry been lobbying for in the Trans Pacific Partnership trade agreement and what are the implications for dietary health? Crit Public Health. 2016;26(5):518-529. doi:10.1080/095815 96.2016.1139689

59. von Tigerstrom B. How do international trade obligations affect policy options for obesity prevention? lessons from recent developments in trade and tobacco control. Can J Diabetes. 2013;37(3):182-188. doi:10.1016/j.jcjd.2013.03.402

60. Puig S. The merging of international trade and investment law. Berkeley J Int Law. 2015;33(1):1-59.

61. Thow AM, McGrady B. Protecting policy space for public health nutrition in an era of international investment agreements. Bull World Health Organ. 2014;92(2):139-145. doi:10.2471/blt.13.120543

62. Thow AM, Annan R, Mensah L, Chowdhury SN. Development, implementation and outcome of standards to restrict fatty meat in the food supply and prevent NCDs: learning from an innovative trade/food policy in Ghana. BMC Public Health. 2014;14:249. doi:10.1186/14712458-14-249

63. World Trade Organization. Mexico - Tax Measures on Soft Drinks and Other Beverages: Report of the Panel. http://www.worldtradelaw.net/ reports/wtopanelsfull/mexico-sweetenertax(panel)(full).pdf. Published online October 7, 2005.

64. United Nations Conference on Trade and Development (UNCTAD). 
Investment Dispute Settlement. Cargill, Incorporated v. United Mexican States (ICSID Case No. ARB(AF)/05/2). Investment Dispute Settlement Navigator. http://investmentpolicyhub.unctad.org/ISDS/ Details/204. Published 2013.

65. United Nations Conference on Trade and Development (UNCTAD). Investment Dispute Settlement. Archer Daniels Midland and Tate \& Lyle Ingredients Americas, Inc. v. United Mexican States (ICSID Case No. ARB(AF)/04/5). Investment Dispute Settlement Navigator. http:// investmentpolicyhub.unctad.org/ISDS/Details/167. Published 2013.

66. United Nations Conference on Trade and Development (UNCTAD). Investment Dispute Settlement. Corn Products International, Inc. v. United Mexican States (ICSID Case No. ARB(AF)/04/1). Investment Dispute Settlement Navigator. http://investmentpolicyhub.unctad.org/ ISDS/Details/166. Published 2013.

67. Bech-Larsen T, Aschemann-Witzel J. A macromarketing perspective on food safety regulation: the Danish ban on trans-fatty acids. J Macromarketing. 2012;32(2):208-219. doi:10.1177/0276146711435262

68. Committee on Technical Barriers to Trade, World Trade Organization. Minutes of the meeting of 21 march 2007. Published online June 2007.

69. Committee on Technical Barriers to Trade, World Trade Organization. Minutes of the meeting of 5 July 2007. Published online August 2007.

70. Committee on Technical Barriers to Trade, World Trade Organization. Minutes of the meeting of 9 November 2007. Published online January 2008.

71. Committee on Technical Barriers to Trade, World Trade Organization. Minutes of the meeting of 20 March 2008. Published online June 2008.

72. Committee on Technical Barriers to Trade, World Trade Organization. Minutes of the meeting of 1-2 July 2008. Published online September 2008.

73. Committee on Technical Barriers to Trade, World Trade Organization. Minutes of the meeting of 5-6 November 2008. Published online January 2009.

74. Rimpeekool W, Seubsman SA, Banwell C, Kirk M, Yiengprugsawan $\mathrm{V}$, Sleigh A. Food and nutrition labelling in Thailand: a long march from subsistence producers to international traders. Food Policy. 2015;56:59-66. doi:10.1016/j.foodpol.2015.07.011

75. Thow AM, Jones A, Hawkes C, Ali I, Labonté R. Nutrition labelling is a trade policy issue: lessons from an analysis of specific trade concerns at the World Trade Organization. Health Promot Int. 2018;33(4):561571. doi:10.1093/heapro/daw109

76. Barlow P, Labonte R, McKee M, Stuckler D. Trade challenges at the World Trade Organization to national noncommunicable disease prevention policies: a thematic document analysis of trade and health policy space. PLoS Med. 2018;15(6):e1002590. doi:10.1371/journal. pmed. 1002590

77. Thow AM, Reeve E, Naseri T, Martyn T, Bollars C. Food supply, nutrition and trade policy: reversal of an import ban on turkey tails. Bull World Health Organ. 2017;95(10):723-725. doi:10.2471/ blt.17.192468

78. Fa'alili-Fidow J, McCool J, Percival T. Trade and health in Samoa: views from the insiders. BMC Public Health. 2014;14:309. doi:10.1186/1471-2458-14-309

79. Committee on Technical Barriers to Trade, World Trade Organization. Minutes of the meeting of 25-26 June 2009. Published online September 2009.

80. Committee on Technical Barriers to Trade, World Trade Organization. Minutes of the meeting of 3-4 November 2010. Published online March 2011.

81. Committee on Technical Barriers to Trade World Trade Organization. Minutes of the meeting of 6-7 March 2013. Published online May 2013.

82. Committee on Technical Barriers to Trade, World Trade Organization. Minutes of the meeting of 17, 19 and 20 June 2013. Published online September 2013.

83. Committee on Technical Barriers to Trade, World Trade Organization. Minutes of the meeting of 30-31 October 2013. Published online February 2014.

84. Committee on Technical Barriers to Trade, World Trade Organization. Minutes of the meeting of 19-20 March 2014. Published online May
2014.

85. Committee on Technical Barriers to Trade, World Trade Organization. Minutes of the meeting of 18-19 June 2014. Published online September 2014.

86. Committee on Technical Barriers to Trade, World Trade Organization. Minutes of the meeting of 5-6 November 2014. Published online March 2015.

87. Committee on Technical Barriers to Trade, World Trade Organization. Minutes of the meeting of 18-19 March 2015. Published online May 2015.

88. Committee on Technical Barriers to Trade, World Trade Organization. Minutes of the meeting of 17-18 June 2015. Published online September 2015.

89. Committee on Technical Barriers to Trade, World Trade Organization. Minutes of the meeting of 4-6 November 2015. Published online February 2016.

90. Committee on Technical Barriers to Trade, World Trade Organization. Minutes of the meeting of 9-10 March 2016. Published online May 2016.

91. Committee on Technical Barriers to Trade, World Trade Organization. Minutes of the meeting of 15-16 June 2016. Published online September 2016.

92. Committee on Technical Barriers to Trade, World Trade Organization. Minutes of the meeting of 10-11 November 2016. Published online February 2017.

93. Carreño I. Chile's black STOP sign for foods high in fat, salt or sugar. Eur J Risk Regul. 2015;6(4):622-628.

94. Carreño I, Dolle T. The Relationship between Public Health and IP Rights: Chile Prosecutes Kellogg's, Nestlé and Masterfoods for Using Cartoons Aimed at Attracting Children. Eur J Risk Regul. 2017;8(1):170-177. doi:10.1017/err.2016.24

95. World Cancer Research Fund International. Building Momentum: Lessons on Implementing a Robust Front-of-Pack Food Label. World Cancer Research Fund International; 2019.

96. Committee on Technical Barriers to Trade, World Trade Organization. Minutes of the meeting of 29-30 March 2017. Published online June 2017.

97. Committee on Technical Barriers to Trade, World Trade Organization. Minutes of the meeting of 14-15 June 2017. Published online September 2017.

98. Committee on Technical Barriers to Trade, World Trade Organization. Minutes of the meeting of 8-9 November 2017. Published online March 2018.

99. Committee on Technical Barriers to Trade, World Trade Organization. Minutes of the meeting of 6-7 March 2019. Published online May 2019.

100. Committee on Technical Barriers to Trade, World Trade Organization. Minutes of the meeting of 20-21 June 2019. Published online September 2019.

101. Committee on Technical Barriers to Trade, World Trade Organization. Minutes of the meeting of 12-15 November 2019. Published online January 2020.

102. World Trade Organization. Brazil - Measures Affecting Imports of Retreaded Tyres (DS332). https://www.wto.org/english/tratop_e/ dispu_e/cases_e/1pagesum_e/ds332sum_e.pdf. Accessed May 28, 2020.

103. Comprehensive and Progressive Agreement for Trans-Pacific Partnership - Chapter 9: Investment. https://www.mfat.govt.nz/assets/ Trans-Pacific-Partnership/Text/9.-Investment-Chapter.pdf. Accessed May 28, 2020.

104. Lukes S. Power: A Radical View. 2nd ed. Palgrave Macmillan; 2005.

105. World Cancer Research Fund International. Building Momentum: Lessons on Implementing a Robust Sugar Sweetened Beverage Tax. World Cancer Research Fund International; 2018.

106. World Cancer Research Fund International. Building Momentum: Lessons on Implementing Robust Restrictions of Food and NonAlcoholic Beverage Marketing to Children. World Cancer Research Fund International; 2020.

107. Thow AM, Jones A, Schneider CH, Labonté R. Global governance of front-of-pack nutrition labelling: a qualitative analysis. Nutrients. 2019;11(2). doi:10.3390/nu11020268

108. Crosbie E, Carriedo A, Schmidt L. Hollow threats: transnational food 
and beverage companies' use of international agreements to fight front-of-pack nutrition labeling in Mexico and beyond. Int $J$ Health Policy Manag. 2020. doi:10.34172/ijhpm.2020.146

109. Chair of the Working Group on Investor-State Dispute Settlement Reform (Working Group III). Remarks of the Chair of Working Group III at the 52nd Session of UNCITRAL (16 July 2019). https:// uncitral.un.org/sites/uncitral.un.org/files/remarks_from_wg_iii_chair_ at_the_52nd_session_of_uncitral.pdf. Accessed May 25, 2020. Published online July $1 \overline{6}, 2019$.

110. Yunus R. RCEP talks to proceed without ISDS. The Malaysian Reserve. https://themalaysianreserve.com/2019/09/13/rcep-talks-toproceed-without-isds. Accessed May 25, 2020. Published September 13, 2019 .
111. Thow AM, Nisbett N. Trade, nutrition, and sustainable food systems. Lancet. 2019;394(10200):716-718. doi:10.1016/s01406736(19)31292-9

112. Kaldor JC, Thow AM, Schönfeldt $H$. Using regulation to limit salt intake and prevent non-communicable diseases: lessons from South Africa's experience. Public Health Nutr. 2018:1-10. doi:10.1017/ s1368980018003166

113. Labonté R, Crosbie E, Gleeson D, McNamara C. USMCA (NAFTA 2.0): tightening the constraints on the right to regulate for public health. Global Health. 2019;15(1):35. doi:10.1186/s12992-019-0476-8

114. Thow AM, Jones A, Huckel Schneider C, Labonte R. Increasing the public health voice in global decision-making on nutrition labelling Global Health. 2020;16(1):3. doi:10.1186/s12992-019-0533-3 